IZA DP No. 6993

Time Limits: The Effects on Welfare Use and Other Consumption-Smoothing Mechanisms

Francesca Mazzolari

Giuseppe Ragusa

November 2012 


\title{
Time Limits: \\ The Effects on Welfare Use and Other Consumption-Smoothing Mechanisms
}

\author{
Francesca Mazzolari \\ Centro Studi Confindustria \\ and IZA \\ Giuseppe Ragusa \\ Luiss University \\ Discussion Paper No. 6993 \\ November 2012 \\ IZA \\ P.O. Box 7240 \\ 53072 Bonn \\ Germany \\ Phone: +49-228-3894-0 \\ Fax: +49-228-3894-180 \\ E-mail: iza@iza.org
}

\begin{abstract}
Any opinions expressed here are those of the author(s) and not those of IZA. Research published in this series may include views on policy, but the institute itself takes no institutional policy positions. The IZA research network is committed to the IZA Guiding Principles of Research Integrity.

The Institute for the Study of Labor (IZA) in Bonn is a local and virtual international research center and a place of communication between science, politics and business. IZA is an independent nonprofit organization supported by Deutsche Post Foundation. The center is associated with the University of Bonn and offers a stimulating research environment through its international network, workshops and conferences, data service, project support, research visits and doctoral program. IZA engages in (i) original and internationally competitive research in all fields of labor economics, (ii) development of policy concepts, and (iii) dissemination of research results and concepts to the interested public.
\end{abstract}

IZA Discussion Papers often represent preliminary work and are circulated to encourage discussion. Citation of such a paper should account for its provisional character. A revised version may be available directly from the author. 
IZA Discussion Paper No. 6993

November 2012

\section{ABSTRACT \\ Time Limits: The Effects on Welfare Use and Other Consumption-Smoothing Mechanisms}

We use data from the Survey of Income and Program Participation covering the period 19892006 to investigate the impact that time limits on receipt of Temporary Assistance for Needy Families have on female-headed family outcomes, including welfare use, employment and living arrangements. The effects of time limits depend on the stock of remaining months of eligibility, which in turn depends on the state time limit and on family's welfare use since the policy was implemented. Since the latter is potentially endogenous to current outcomes, we form a prediction of remaining eligibility based on state rules and observable family characteristics. For families who are predicted to have hit the limit, we find evidence of enforcement of the policy, which causes monthly income from welfare to drop by an average of $\$ 250$. This loss is not offset by increases in other income sources: not only there is no significant change in earnings (despite a sizable increase in the likelihood that the mother works), but also income from other transfer programs (such as SSI and Food Stamps) decreases - resulting in increasing rates of deep poverty among these families. Additional analyses suggest that doubling up is a way for families who timed out of welfare to share housekeeping expenses.

JEL Classification: J20, H53

Keywords: $\quad$ welfare, time limits, consumption-smoothing

Corresponding author:

Francesca Mazzolari

Centro Studi Confindustria

Viale dell'Astronomia, 30

00144 Roma

Italy

E-mail: f.mazzolari@confindustria.it

\footnotetext{
* The authors thank Caroline Danielson for very helpful discussions on data issues, and James Sullivan, Melissa Schettini Kearney and other participants at the NPC-Census conference "The Survey of Income and Program Participation (SIPP): Research on Health Insurance, Welfare and Child Support" (Washington DC, October 3, 2008) for comments and suggestions. This project was supported with a grant from the National Poverty Center at the University of Michigan with funds provided by the U.S. Census Bureau, Housing and Household Economics Statistics Division. The opinions and conclusions expressed herein are solely those of the author(s) and should not be construed as representing the opinions or policy of the NPC or of any agency of the Federal government.
} 


\section{Introduction}

Of all the U.S. welfare reform developments of the 1990s, the elimination of the entitlement status through the imposition of time limits on welfare receipt is among the most radical changes relative to previous policy. Under the Aid to Families with Dependent Children (AFDC) program, all single-parent families with at least one child under age 18 could receive benefits as long as they satisfied some income and wealth eligibility criteria. In contrast, the Personal Responsibility and Work Opportunity Reconciliation Act of 1996 (PRWORA) prohibits states from using federal Temporary Assistance for Needy Families (TANF) funds to provide benefits beyond a 60-month lifetime limit. Many states have opted for even shorter limits. ${ }^{1}$

Time limits might affect welfare use through both mechanical and behavioral effects. The direct mechanical effect arises from the fact that a family that reaches the limit should be dropped from the rolls (if the limit is enforced). Even before limits become binding, there might be behavioral responses of recipients and eligibles: forward-looking families may reduce their current welfare use in order to preserve their welfare eligibility as insurance against a negative event in the future (Grogger and Michalopoulos 2003, GM hereafter; Swann, 2005). Most of the empirical literature has focused on how time limits affect welfare use before they actually become binding, and has found some support for the existence of behavioral responses. Largely because of data limitations, very few studies have attempted at estimating

\footnotetext{
${ }^{1}$ Moffitt (2003) provides a summary of the changes from AFDC to TANF. For reviews of the economic literature on the effects of the reform on welfare use, see Blank (2002), and Grogger, Karolyn and Klerman (2002). For a survey of state time limit policies, see Bloom et al. (2002).
} 
the degree of enforcement of time limits. Even less is known on the outcomes of families hitting the limit and being dropped from the rolls.

Both the mechanical and behavioral effects of time limits depend on the stock of remaining months of eligibility, that in turn depends on (i) the state time limit - expressed in terms of available months of eligibility over a family lifetime, and on (ii) family's welfare use since the policy was implemented. To define this crucial determinant of take-up and eligibility under time limits, this paper uses data from the Survey of Income and Program Participation (SIPP). Because of its longitudinal design and collection of information on monthly welfare use, remaining months of eligibility can be partly recovered in the SIPP from a family's transitions into and out welfare observed during the sample period. ${ }^{2}$ However, since the SIPP consists of several separate panels, in-sample information must be complemented with information from the retrospective questions on past welfare use asked at the beginning of each panel. Using this approach and pooling data from the 2001 and earlier SIPP panels, Mazzolari (2007) estimates that time limits decreased welfare use by 25 percent between 1996 and 2003, with around twenty percent of the reduction due to behavioral responses, and the rest due to families hitting the limit.

This paper extends previous work on the effects of time limits in several important ways. First, by including in the analysis data from the 2004 SIPP panel, we observe families through December 2006. It was not until the early 2000s that the first group of women who were continuously on welfare since TANF was enacted began to hit the 60 -month time limit set in

\footnotetext{
${ }^{2}$ The Current Population Survey, on the contrary, has limited information on duration of cash assistance.
} 
many states. As the share of the population hitting the limit grows, there are more opportunities to assess the degree of enforcement of the policy and its effects. Second, we contribute to the existing literature by evaluating the effects of time limits on a variety of outcomes other than welfare use, such as employment and other income sources potentially available to families banking or losing TANF eligibility. As such, the analysis help assessing whether time limits (i) promoted families' transition from welfare to work, (ii) made them dependent on other kinds of transfers (e.g., from other government programs), or (iii) made families worse off and increased their material hardship. Finally, since information on recipiency history collected at the beginning of each SIPP panel is not always sufficient to recover welfare use since time limit implementation (and the problem is more serious in the 2004 panel), from a methodological point of view we improve on previous work in the way we forecast remaining months of eligibility as of the time an individual first enters a SIPP panel. Specifically, we do so by fitting a model for past welfare use on a sample drawn from the end of the previous panel. In addition, we use cumulative administrative counts on welfare cases to improve our predictions.

\section{Time limit policies}

\section{A. The federal time limit policy}

PRWORA prohibits states from using federal TANF funds to provide assistance to families with an adult recipient for more than 60 cumulative months. ${ }^{3}$ In practice, though, the federal

\footnotetext{
${ }^{3}$ The "clock" for the federal 60-month lifetime limit started when each state implemented the TANF program (between September 1996 and July 1997).
} 
time limit is not a limit on benefit receipt for individual families; rather, it is a funding constraint that shapes state policy decisions (Bloom et al., 2002). As a matter of fact, PRWORA replaced a matching fund arrangement under AFDC, in which federal funding moved up and down with state funding, with a system in which states are given federal block grants and, as residual claimants, considerable discretion in how to allocate them. Moreover, the federal limit does not apply to state funds - which gives states even broader flexibility in designing time-limit provisions. As a result, under PRWORA states can establish a 60-month time limit, a shorter time limit, or no time limit at all. They also have discretion in setting exceptions to the federal time limit, including circumstances under which a month of TANF assistance does not count towards the limit (exemptions) and circumstances under which TANF assistance may be continued even though a family has reached their limit (extensions).

Exemptions from the federal limit can generally be granted by states under one of the following three circumstances. First, the federal time limit does not apply to cases in which no adult is included in the welfare grant ("child-only cases"). Second, a family may be exempt from accrual of months under the federal five-year time limit based on an approved welfare reform waiver policy. ${ }^{4}$ Third, families receiving assistance from state-only funding are not subject to the federal time limit. ${ }^{5}$

\footnotetext{
${ }^{4}$ A state may have received a waiver under the former AFDC program that authorized it to implement a time limit on cash assistance. If the TANF time limit was inconsistent with the state's waiver time limit, the state was allowed to follow its waiver policy rather than the TANF policy until the expiration of the waiver. A dozen states filed certifications to follow a waiver policy, claiming inconsistencies that typically involved the exemption or extension policies under a state's waiver.

${ }^{5}$ States can choose to segregate some or all of their state "maintenance-of-effort" (MOE) funds from federal funds and/or can create a separate state program (SSP) funded solely with state MOE dollars.
} 
As regards extensions, states can use the federal TANF block grant to extend assistance beyond 60 months to up to 20 percent of the state caseload, including child-only cases. PRWORA allows the states to extend assistance based on hardship. States can also finance benefits to a family beyond the 60-month limit using state-only funding.

\section{B. State time limit policies}

States have used their flexibility under the federal law to adopt a wide variety of time limits that differ not only in length, but also in other ways. Two states (Vermont and Michigan) decided to impose no limit at all. ${ }^{6}$ All other states implemented some kind of time limit policy. Families accrue months toward a state time limit starting from the date of implementation of the policy in the state, which in 15 states differs from the date of TANF certification (Table 1).

Twenty-four states have adopted the simple PRWORA standard of a 60-month lifetime limit, while five states impose a lifetime limit shorter than 60 months (ranging between 24 and 48 months). Eleven states impose not only a lifetime limit (of 60 or less months) but also "intermittent limits" that are implemented either by limiting individuals to receive no more than $x$ months of receipt in every $y$ months of calendar time, or by obliging recipients to stay out of the program for $z$ months after receiving benefits for $x$ months. One state (Massachusetts) imposes no lifetime limit, but only intermittent limits. Finally, eight states have relaxed the time limits implicit in PRWORA by adopting "reduction" rather than

The 60-month federal time limit does not apply toward assistance funded with segregated funds or through an SSP.

\footnotetext{
${ }^{6}$ Vermont operated under a waiver, now expired. Michigan has implemented a 48-month limit effective October 1, 2007, for individuals participating in the state's Jobs Education and Training program.
} 
termination policies (six have lifetime limits, while two have only intermittent limits). A reduction limit is a limit only for adults, so that children can continue to receive benefits beyond 60 months.

In the empirical exercise presented in this paper, we follow state time limit policies in defining the date of implementation $\left(\overline{\mathrm{T}}_{\mathrm{s}}\right)$ and the number of months of eligibility available under time limits $\left(\mathrm{N}_{\mathrm{s}}\right)$. In particular, unless otherwise noted, $\mathrm{N}_{\mathrm{s}}$ is set to be equal to the most binding time limit imposed in the state (that is, the intermittent time limit if in place).

\section{The effects of time limits}

Time limits could affect individual behavior in several ways. First, even before limits become binding, forward-looking families may reduce their current welfare use in order to preserve their welfare eligibility. So, women who have already started to receive welfare may be persuaded to find jobs and leave the rolls faster to avoid using up their months of eligibility. For the same reason, people who are working and off welfare might be more likely not to enter the rolls. The existence of an incentive to bank welfare eligibility for the future is conditional on several assumptions. First, banking incentives can only arise if there is no borrowing or saving, as in the GM model, or in the presence of a high enough benefit reduction rate - the rate at which other income is taxed in the welfare benefit formula (Fang and Keane, 2004). Another crucial assumption for the existence of banking behaviors is that the future matters. Evidence supporting this assumption is provided by Swann (2005), who estimates a high discount factor (ranging from 0.81 to 0.84 ) for women in a dynamic model of welfare use, work and marriage choices. A further requirement is that welfare eligible individuals are aware of the existence of time limits and of how many periods they have left. As documented in 
Bloom et al. (2002), the state time-limit policy is generally communicated to recipients when they enroll, and in many states the number of months remaining on a recipient's clock is routinely announced with each welfare check. Despite these practices, on data from the 2002 National Survey of America's Families, Zedlewsky and Holland (2003) find that 16 percent of welfare recipients report that they were not told they had a time limit, and another 21 percent report they were told but that they did not know for how many more months they could receive benefits.

Time limits may also discourage women from ever participating in a welfare program for reasons other than banking effects. Stigma arising from receipt of welfare benefits has been proposed as an explanation for the low take-up rate among eligible individuals (Moffitt 1983). If stigma depends heavily on whether one has ever received benefits, then welfare eligible individuals may decline to ever make use of the program if the years of eligibility are shortened enough.

Finally, women might not respond to time limits at all until their benefits are canceled, at which point they might be more likely to go to work to replace their lost income. However, long-term recipients may have skill deficits and personal and family problems that make it impossible for them to work steadily. If so, time limits would cut off benefits of people who cannot replace cash assistance with earnings or other income, and, as a result, they would cause material hardship for these families.

\section{Empirical evidence}

Soon after enactment, some analysts were projecting that as many as 2 million families and 3.8 million children would hit the 5-year federal limit (Duncan et al. 2000). These projections, 
however, were static; that is, they did not take into account changing economic conditions or welfare use behaviors in the post-reform period. Because of the strong economy of the late 1990s and of the many new rules that made welfare less generous, these calculations likely overstated the number of families hitting the limits. Moreover, at the time of PRWORA enactment making predictions on the number of involuntary exits due to time limits was complicated by the fact that this number depended on how states would implement the policy, that is, (i) whether they would exempt some or all families from time limits, and (ii) whether they would actually cancel the welfare grants of families reaching the limit, or would rather extend their eligibility.

Largely because of the scarcity of data on flows onto ad off of welfare, whether TANF time limits have resulted in a substantial number of involuntary exits remains an open question. ${ }^{7}$ The approach taken in Bloom et al. (2002) and Farrell et al. (2008) to answer this question is to count the number of families who timed-out as reported by states. They estimate that the total number of cases closed due to time limits by December 2001 and by September 2005 was, respectively, 93,000 and 257,000. For a number of reasons, however, these figures are likely to underestimate the number of families who had their benefits canceled due to time limits. ${ }^{8}$

\footnotetext{
${ }^{7}$ More broadly, we have very limited information on the ways in which time limits are actually being implemented and are affecting families. We know more only about a few specific states. For example, Bitler, Hoynes and Gelbach (2006) find that the 21-month time limit policy included in Connecticut's Jobs First program was binding for a substantial number of women, and that income was reduced for a non-trivial share of the income distribution after time limits took effect. For the case of a county in Minnesota, Pavetti and Kauf (2006) describe the problems faced by families who are hitting the limits.

${ }^{8}$ For example, these figures do not include cases that were closed just prior to reaching time limits or after receiving an extension. See Bloom et al. (2002) for a discussion of the limitations of the data.
} 
Most of the empirical literature on the effects of time limits has focused on how time limits affect welfare use before they actually become binding. Several early studies using only crossstate variation in the timing of implementation of time limits estimate that they had no significant effect on welfare use (CEA 1997, 1999; Moffitt 1999; Schoeni and Blank 2000; Ziliak et al. 2000). A shortcoming of these studies is that they constrain the effects of time limits to be independent of personal characteristics. On the contrary, the GM's model predicts that the "option value" of banking welfare eligibility is decreasing in the stock of remaining months of eligibility and increasing in the time horizon over which benefits may be used (that is, given the AFDC/TANF categorical restriction, as long as minor children live in the home). The most recent empirical literature tests for and provides evidence consistent with reducedform predictions of the GM's model. GM - on data from a reform demonstration in Floridaand Grogger $(2002,2003,2004)$-on nationally representative data- allow for age-dependence in the effects of time limits to test the prediction that behavioral effects should be greater among families with younger youngest children, because they have longer horizons of categorical eligibility. They find that time limits have statistically significant and economically sizable negative effects on welfare use. For example, Grogger (2004) estimates that behavioral responses to time limits account for 12 to 13 percent of the 1993-1999 decline in welfare use. A shortcoming of identifying the effects of time limits through age-dependent effects is that this approach is theoretically valid only at the moment of time limit implementation, while as time passes it only correctly identifies the incentive to bank benefits perceived by people who have not used any of them. Fang and Keane (2004) estimate a reduced-form specification for welfare utilization that captures the effects of remaining eligibility through the inclusion of the minimum stock of benefits that a woman would possess if she always received welfare since her clock started. Time limits are found to explain 11 percent of the overall 1993-2002 decline 
in welfare use among single-headed families. However, also in this approach the characterization of the effects of time limits worsens as time passes since the limit is introduced.

Using SIPP data, Mazzolari (2007) improves the characterization of the incentives and constraints faced by potential recipients under time limits by including in the analysis information on the number of remaining months of eligibility. This is essential to test the structural predictions of the GM model on the behavioral effects of time limits, but also to separately identify the mechanical effects of this provision. The estimation results indicate that time limits decreased welfare use by 25 percent between 1996 and 2003, with only around twenty percent of the reduction due to behavioral responses, and the rest due to families hitting the limit.

There is a very scarce literature on the effects of time limits on outcomes other than welfare use. Relying on the fact that the effects of time limits should vary by the age of the youngest child in the family, Grogger (2003) estimates that this policy had substantial effects both on welfare use and employment, but somewhat lesser effects on labor supply, and little if any effects on earnings and income. When comparing states with short and long time limits in the early 2000s, Leonard and Mas (2005) provide evidence of a noticeable increase in the infant mortality rate in the early 2000 s in the former group of states, but not in the latter-occurring 
primarily among low-educated women with at least one previous live-birth, that is, a group who could have plausibly timed out of TANF. ${ }^{9}$

\section{Empirical model}

\section{The effects of time limits on welfare use}

On samples of single mothers drawn from the SIPP panels, we estimate the following model for welfare use:

(1) $\mathrm{p}_{\mathrm{its}}=\mathrm{X}_{\mathrm{it}} \lambda+\mathrm{V}_{\mathrm{ts}} \phi+\mathrm{I}\left(\mathrm{t} \geq \overline{\mathrm{T}}_{\mathrm{s}}\right)\left\{\alpha \mathrm{I}\left(0<\mathrm{S}_{\mathrm{its}}<\mathrm{H}_{\mathrm{it}}\right)+\gamma \mathrm{I}\left(\mathrm{S}_{\mathrm{its}} \geq \mathrm{H}_{\mathrm{it}}\right)+\delta \mathrm{I}\left(\mathrm{S}_{\mathrm{its}} \leq 0\right)\right\}+\eta_{\mathrm{s}}+\mathrm{Year}_{\mathrm{t}}+\varepsilon_{\mathrm{its}}$

where $p_{\text {its }}$ takes on the value one if woman i living in state s received AFCD/TANF benefits in month $\mathrm{t} ; \mathrm{X}_{\mathrm{it}}$ and $\mathrm{V}_{\mathrm{ts}}$ are respectively sets of socio-demographic characteristics and state-level policy and economic factors, and I(.) is the indicator function (which is unity whenever the statement in parentheses is true, and zero otherwise). $S_{\text {its }}$ is the remaining stock of months of welfare eligibility and $\mathrm{H}_{\mathrm{it}}$ is the eligibility horizon. Specifically, $\mathrm{S}_{\mathrm{its}}=\mathrm{N}_{\mathrm{s}}-\sum_{\mathrm{j}=\overline{\mathrm{T}}_{\mathrm{s}}}^{\mathrm{t}-1} \mathrm{p}_{\mathrm{ijs}}$ where $\mathrm{N}_{\mathrm{s}}$ is the state time limit and $\overline{\mathrm{T}}_{\mathrm{s}}$ is the date when the state started to count months toward the limit; and $\mathrm{H}_{\mathrm{it}}=(12 * 18)-\mathrm{A}_{\mathrm{it}}^{\mathrm{y}}$, where $\mathrm{A}_{\mathrm{it}}^{\mathrm{y}}$ denotes the age in months of the youngest child.

Equation (1) allows testing the following hypotheses on the effects of time limits:

\footnotetext{
${ }^{9}$ This result is consistent with a positive effect of maternal participation in the AFDC program on the well being of new-born children (Currie and Cole, 1993).
} 
(i) Unconstrained hypothesis: When the clock is running $\left(\mathrm{t} \geq \overline{\mathrm{T}}_{\mathrm{s}}\right)$, individuals with remaining stock of benefits not smaller than their eligibility horizon $\left(\mathrm{S}_{t} \geq \mathrm{H}_{t}\right)$ should behave as if time limits were not implemented $(\gamma=0)$.

(ii) Banking hypothesis: If they are forward-looking, individuals with incomplete coverage under time limits -that is, with a remaining stock of benefits less than the eligibility horizon $\left(0<\mathrm{S}_{\mathrm{t}}<\mathrm{H}_{\mathrm{t}}\right)$ - should have an incentive to bank their welfare eligibility for periods of adverse wage shocks, and so should participate in welfare less than people not facing time limits $(\alpha<0)$.

(iii) Enforcement hypothesis: Most state welfare laws do include the option of extensions, usually because the family faces a particular hardship or because the parent is unable to find work despite "diligent efforts." Most states also allow for exemptions, primarily for recipients that are incapacitated or are victims of domestic violence (Bloom et al., 2002). As such, the degree of enforcement of time limits is an empirical question. If time limits are enforced, then exhausting benefits relative to the statewide time limit $\left(S_{t} \leq 0\right)$ should predict a drop in the probability of using welfare $(\delta<0)$.

The strategy for identifying the effects of time limits is based on the interaction of state, time and individual variation. First, each state s has a specific total stock of benefits available denominated in months of benefit receipt $\left(\mathrm{N}_{\mathrm{s}}\right)$, and started to count months toward the limit at a specific date $\left(\overline{\mathrm{T}}_{\mathrm{s}}\right)$. Second, individuals may live in a period when time limits are not implemented $\left(\mathrm{t}<\overline{\mathrm{T}}_{\mathrm{s}}\right)$; when limits are implemented $\left(\mathrm{t} \geq \overline{\mathrm{T}}_{\mathrm{s}}\right)$, there is variation in the length of the exposure to the policy, defined by the number of periods elapsed since implementation 
$\left(\mathrm{t}-\overline{\mathrm{T}}_{\mathrm{s}}\right)$. Finally, individuals have different eligibility horizons $\left(\mathrm{H}_{\mathrm{it}}\right)$ and remaining eligibility $\left(\mathrm{S}_{\mathrm{its}}\right)$ - which depend on the age of their children and their past welfare use.

As apparent from the sample restriction to single mothers and from the definition of the eligibility horizon in terms of ages of living children, the identification strategy assumes that marital status and fertility decisions are exogenous to time limit policies. This assumption is justified by the fact that the empirical literature on the effects of welfare reform on family composition decisions is mixed, and for some inconclusive. ${ }^{10}$ However, the lack of evidence from the available data is also consistent with marriage and fertility patterns being more sluggish and resistant to change than welfare (or work) behavior. If more findings became available about significant effects of welfare reform on family composition decisions, then the exogeneity assumption would turn less innocuous.

There are several issues to be dealt with in the identification of the effects of time limits in Equation (1). First, to separate the effects of time limits from the collective effect of other reform components (such as work requirements), we exploit the fact that the dates since time limits started to be counted do not overlap completely with either waiver or TANF implementation dates. In practice, we include in $\mathrm{V}_{\text {ts }}$ two welfare reform variables: (i) a dummy that takes the value of one if the state in which a woman lives has a "major" statewide waiver in effect in month $\mathrm{t}$ (the indicator is turned off when TANF is implemented in the state) and (ii) a dummy that is equal to one in all months after the state first implemented its TANF

\footnotetext{
${ }^{10}$ See Grogger, Karolyn and Klerman (2002) and Blank (2007) for reviews.
} 
program. ${ }^{11}$ In order to disentangle the effects of time limits from those of other factors that influence welfare use, $\mathrm{V}_{\text {ts }}$ also includes the monthly unemployment rate, the AFDC/TANF maximum monthly benefit for a family of three, and the Earned Income Tax Credit (EITC) maximum payment. ${ }^{12}$

Equation (1) also includes state fixed effects $\left(\eta_{s}\right)$ and state linear and quadratic trends, which are meant to address the issue of policy endogeneity. This would arise if unobservable determinants of welfare use that vary between states and over time (included in the error term $\left.\varepsilon_{\text {its }}\right)$ were correlated with the state level policy variables controlled for in Equation (1)..

Finally, including the actual remaining stock of benefits $S_{\text {its }}$ in a model that explains current welfare use $p_{\text {its }}$ would cause serious endogeneity concerns. This is because $\mathrm{S}_{\text {its }}$ depends on individual welfare participation in previous periods, which is likely to be correlated with some unobservable factors that also explain $p_{\text {its. }}$. For example, a woman with unobserved barriers to work is more likely to have received benefits in the past and to have a low $\mathrm{S}_{\mathrm{its}}$, but she is more likely to be receiving benefits today as well. Also, a woman who used welfare at time $\mathrm{t}-1$ because of a negative wage shock starts period t with a depleted stock of benefits, but she is also more likely to use welfare because of state dependence (Chay, Hoynes and Hyslop 1999). Both cases would result in a relationship between $\mathrm{S}_{\text {its }}$ and $\mathrm{p}_{\text {its }}$ of the opposite sign than that

\footnotetext{
${ }^{11}$ For dates and sources, see Table 1 . The table reports the dates in which states (1) received waivers from the AFDC rules (in the early 1990s), (2) they implemented their TANF programs (between September 1996 and January 1998), and (3) started to count months towards the limits $\left(\mathrm{T}_{\mathrm{s}}\right)$.

${ }^{12}$ The variables included in $\mathrm{V}_{\mathrm{ts}}$ vary by state and time, some at the monthly level (unemployment rate and waiver and TANF dummies), the others on a yearly basis. The EITC maximum credit also varies by family size
} 
predicted by the banking hypothesis. Moreover, given that states may grant extensions to people who have exhausted their benefits but can prove to the welfare office to be facing a particular hardship or not to be able to find work despite diligent efforts, the event $S_{\text {its }} \leq 0$ is likely to be endogenous to some unobserved factors that also make it more likely to be granted to continue to receive benefits. So, we expect the estimate of $\delta$ to be upward biased.

Following Mazzolari (2007), we address the endogeneity of S by isolating variation in remaining months of eligibility at each point in time arising from differences in the timing and nature of state time limit policies, individual exposure to time limits and an exogenous prediction of average welfare use based on socio-demographic characteristics. In particular, we start from noticing that welfare use counting toward the limit can be expressed as the fraction of time a woman actually spent on welfare $\left(\mathrm{k}_{\mathrm{it}}\right)$ of the total time she might have spent since her state started her clock $\left(\mathrm{E}_{\mathrm{its}}\right)$. As a result, we can write remaining eligibility as $\mathrm{S}_{\mathrm{its}}=\mathrm{N}_{\mathrm{s}}-\mathrm{k}_{\mathrm{it}} * \mathrm{E}_{\mathrm{its}}$, where $\mathrm{E}_{\mathrm{its}}$ equals the minimum between the number of months elapsed since the implementation of time limits $\left(\mathrm{t}-\overline{\mathrm{T}}_{\mathrm{s}}\right)$ and the age in months of a woman's oldest child $\left(\mathrm{A}_{\mathrm{it}}^{\mathrm{o}}\right)$, that is $\mathrm{E}_{\mathrm{its}}=\min \left\{\left(\mathrm{t}-\overline{\mathrm{T}}_{\mathrm{s}}\right), \mathrm{A}_{\mathrm{its}}^{\mathrm{o}}\right\}$. As long as the legislative environment is taken as exogenous, $\mathrm{E}_{\text {its }}$ identifies an exogenous source of variation in $\mathrm{S}_{\text {its. }}$ The fraction of time individual $\mathrm{i}$ actually spent on the rolls $\left(\mathrm{k}_{\mathrm{it}}\right)$, however, is likely be endogenous to $\mathrm{p}_{\mathrm{its}}$. To address this issue, we simulate remaining benefits as $\mathrm{Z}_{\mathrm{its}}=\mathrm{N}_{\mathrm{s}}-\widetilde{\mathrm{k}} * \mathrm{E}_{\mathrm{its}}$, where $\tilde{\mathrm{k}}$ is a presumably exogenous prediction, empirically obtained as the average welfare recipiency rate predicted at the national level and in the pre-reform period on the base of some socio-demographic characteristics. Specifically, the results presented in Section VII are obtained using a set of four weights that represent average national pre-reform welfare participation by education (two 
categories: (i) less than a high school degree, (ii) high school degree or more) and number of children (two categories: (i) one or two children, (ii) more than two children). ${ }^{13}$

A final identification issue arises from the possibility that other determinants of welfare use may have effects that vary by children's ages, or by the other characteristics that define $\tilde{\mathrm{k}}$. To allow for this case, we generalize Equation 1 and allow the variables in $\mathrm{V}_{\text {ts }}$ to interact with the age of the youngest and the oldest child, as well as a woman's education and number of children.

To summarize, variants of Equation (1) are estimated by instrumental variables (IV), where the three time limit variables (which are functions of $\mathrm{S}_{\mathrm{its}}$ ) are instrumented by the same functions but defined on $\mathrm{Z}_{\text {its. }}$ Estimation results from first stage regressions (reported in Table 5) show that the instrumental variables are statistically significant predictors of the endogenous variables. The F-statistics on the joint significance test of the three instruments is remarkably high in the equations for banking effects and for the non-binding case (Columns 1 and 2), while hitting the limit (column 3 ) - the less frequent event (2 percent of the sample falls in this category) - appears to be the most difficult one to predict: the F-statistics is much lower than in the other cases, but still largely above the critical value of 10 (Staiger and Stock 1997).

\footnotetext{
${ }^{13}$ There are many possible sets of weights we can calculate using the socio-demographic characteristics that have the highest predictive power for pre-reform welfare participation (number of children, education, race, marital status, age). For a discussion of robustness checks for the choice of $\mathrm{k}$, see Mazzolari (2007). Also, it must be noted that the single weights $\mathrm{k}=0$ and $\mathrm{k}=1$ would correspond to and share the problems of the approaches taken (in a reduced-form specification) by Grogger $(2002,2003$, 2004) and Fang and Keane (2004) respectively. Also, setting $\mathrm{k}=0$ would prevent testing the enforcement hypothesis.
} 


\section{The effects of time limits on other income-generating activities}

Beyond welfare use, we use specification (1) to test the effects of time limits on other ways a single mother may have to generate income and, more broadly, to finance consumption for herself and her children, including (i) employment and earnings, (ii) participation in other welfare programs (e.g., Food Stamps, Supplemental Security Income), (iii) income sharing from cohabitation.

For families banking their months of eligibility, we would expect to observe changes in these other variables that at least partly offset the income losses from giving up welfare. Since the banking hypothesis implicitly assumes that families have other alternative ways to finance consumption while saving eligibility, this analysis may serve as an indirect test for this hypothesis. Second, assessing which alternative sources of income a family that is plausibly banking benefits is relying on is an important policy question, since it sheds light on whether the reform succeeded in making benefits perceived as temporary while promoting a transition from welfare to work, or instead made families dependent on other kinds of transfers or forced them to potentially disruptive changes in living arrangements.

For families running out of eligibility, the analysis is informative of the alternative ways to finance consumption that are available to them. This analysis is important for two reasons. First, it may serve as a way to assess whether TANF benefits were crowding-out other income sources. This is a crucial policy issue - that has received only limited empirical investigation in the pre-reform period (Gruber, 2000). Second, assuming we had a complete enough list of income generating activities other than welfare transfers, the analysis would indirectly shed light on whether hitting the limit is likely to be associated with changes in the material 
hardship for single mothers and their children. There are three main issues that hinder our ability to learn about the material well-being of families from this approach. First, even if the SIPP is a very rich survey, we cannot assume it includes information on all of the possible sources of income available to families. Second, income tends to be underreported. Finally, after-tax income should be measured. Consumption would certainly be a better measure of well-being than income. In their study of well-being changes for single mother headed families over the 1990s, Meyer and Sullivan (2008) show how changes in measured income sharply differ from changes in consumption. Unfortunately, the small sample sizes of the U.S.

Consumer Expenditure surveys hinder our ability to complement the present analysis with a study of the effects of time limits on consumption. ${ }^{14}$

\section{Data and variable construction}

We use data from the 1990, 1991, 1992, 1993, 1996, 2001 and 2004 SIPP panels, whose combined sampling periods extend from October 1989 to December 2006. Each panel constitutes an independent sample of the U.S. population. Data are collected at four-month intervals (known as "waves"); however, at each interview, respondents are asked to provide information covering the four months since the previous interview, so that the data are on a monthly basis. Until 1993, a new panel was started annually, so that there were usually several panels in progress simultaneously - each one including on average 8 to 9 waves (that is, spanning 32 to 36 months of data). After 1993, the SIPP was redesigned to include larger non-

\footnotetext{
${ }^{14}$ The SIPP collects information on direct material well-being measures (such as difficulty paying utilities or rent), but only in a topical module asked once per panel.
} 
overlapping panels. The 1996 and 2004 panels include 12 waves, while the 2001 panel includes 9 waves. $^{15}$

The sample of analysis is restricted to single mothers (that is, the primary target for cash assistance under the U.S. law) between the ages of 15 and 55 living in states that are separately identified in the SIPP. ${ }^{16}$ The resulting sample is given by 544,234 monthly observations on 20,511 women. $^{17}$

The first advantage of using samples drawn from the SIPP is the availability of data on monthly receipt of income from AFDC/TANF programs. This is the appropriate variable of interest given that welfare eligibility is determined on a monthly basis and time limits are expressed in terms of available months of eligibility. Also, the fact that respondents are interviewed every four months reduces misreporting due to recollection problems that can be serious in yearly datasets. Underreporting, however, is still present in the SIPP (Jabine et al. 1990; Card et al. 2004). If underreporting changes over time, then time series comparisons are problematic. In particular, the estimates in the present study would be biased in the same direction as the predicted effects of time limits on welfare use if elimination of the entitlement for benefits increased underreporting for TANF participation. We explore this issue in the next section.

\footnotetext{
${ }^{15}$ As of the time of this writing, only the first 9 waves of the 2004 panel were available.

${ }^{16}$ The nine excluded states are AK, ID, IA, ME, MT, ND, SD, VT and WY.

${ }^{17}$ Given that previous work shows that respondents tend to give the same response for all four months within a wave (Blank and Ruggles 1996), we have tested the robustness of our results to restricting the sample to observations pertaining to the month before the interview.
} 


\section{E. Assessing underreporting of welfare participation in SIPP}

An indicator of measurement error in SIPP-reported welfare use is the discrepancy between cases receiving welfare assistance estimated in the SIPP and administrative caseload data.

Figure 1 illustrates this comparison. Data on monthly counts of welfare cases are from the Office of Family Assistance (OFA) within the U.S. Department of Health and Human Services' Administration for Children and Families. ${ }^{18}$ OFA collects these data from states. Starting in fiscal year 2000, a majority of states set up parallel cash assistance programs, one for federally-funded and one for state-funded cases, and started to report them separately to OFA. The blue line in Figure 1 plots monthly administrative counts that are aggregated at the national level and include both federally- and state-funded cases.

The other lines plot the number of cases estimated in the SIPP, both by panel and across panels. The SIPP-based estimates of welfare cases are systematically lower than the administrative counts, but overall they track fairly well the caseload surge in the early 1990s and its subsequent drop. Even an eyeball comparison, however, reveals changes in the discrepancy between administrative and SIPP-based estimates both within and across SIPP panels. There is a clear tendency for the discrepancy to rise within panels. One explanation for this pattern is that individuals with a higher probability of welfare use may have higher attrition rates, so that welfare cases are downward biased in later months of each panel. Indeed, in the 1990-1993 SIPP panels, Card, Hildreth and Shore-Sheppard (2004) find that attrition rates are higher for people in poverty. Selective attrition patterns imply that trends in welfare cases

${ }^{18}$ Available at http://www.acf.hhs.gov/programs/ofa/data-reports/caseload/caseload archive.html. 
estimated within a panel are downward-biased relative to trends across panels. This can clearly explain some of the differences in estimated counts across the 1990-1993 panels. Also, in light of the 1996 redesign — that abandoned the overlapping panel structure-we should not expect underreporting patterns to be constant over the sample period that is relevant for our analysis. Finally, when comparing estimates from the more recent panels, a striking feature of Figure 1 is that the discrepancy from administrative data appears to be significantly lower (and more stable) in the 2004 panel than in the previous ones.

Figure 2 restricts the comparison between administrative and SIPP-based estimates to the case of single-parent families. While the qualitative patterns are similar, the magnitude of the discrepancy between the two sources is significantly larger in this case. This suggests that underreporting of welfare use in the SIPP is more pronounced among the population of interest for this study.

Since in our paper identification of the effects of time limits stems from state policy variation, it is crucial for us to assess whether underreporting is systematically related to the timing of state time limit implementation. To investigate this issue, we estimate the following model for the discrepancy between administrative counts and SIPP-based estimates calculated by month and state, $\mathrm{D}_{\mathrm{ts}}$ :

$$
\mathrm{D}_{\mathrm{ts}}=\mathrm{I}\left(\mathrm{t} \geq \overline{\mathrm{T}}_{\mathrm{s}}\right)+\eta_{\mathrm{s}}+\mathrm{Year}_{\mathrm{t}}+\varepsilon_{\mathrm{ts}}
$$

Estimation results (reported in Table 2) show that the discrepancy is negatively correlated with the time limit implementation dummy, that is, underreporting appears to be systematically lower when individuals face time limits. This implies that changes in underreporting are expected to bias our estimates against finding a negative effect of time limits on welfare use. 
Importantly, when including state and year effects (column 3) - also included in equation (1) the magnitude of differences in underreporting before and after time limit implementation shrinks significantly.

\section{F. Imputing remaining months of eligibility}

Both the mechanical and behavioral effects of time limits depend on the stock of remaining months of eligibility, which in turn depends on family's welfare use since the policy was implemented. The SIPP provides the most valuable source of data to define this crucial determinant of take-up and eligibility under time limits. Information on individual prior welfare participation since time limit implementation can be obtained in the SIPP using both in-sample information and retrospective questions asked at the beginning of the panel. Individuals sampled in the 1990-1993 panels (whose sampling periods extend to December 1995) did not face time limits, since states implemented the policy after December $1995 .{ }^{19}$ As regards the 1996 panel — that covers the period December 1995-February 2000 — the number of months of individual welfare use since the clock started to tick $\left(\mathrm{M}_{\mathrm{its}}\right)$ can be calculated using in-sample information. We then build remaining benefits $S_{\text {its }}$ as the difference between the state limit $\left(\mathrm{N}_{\mathrm{s}}\right)$ and $\mathrm{M}_{\mathrm{its} .}{ }^{20}$ In the 2001 and 2004 panels (whose sampling periods are, respectively,

\footnotetext{
${ }^{19}$ The only exception is Arizona that started to count months towards the limit in November 1995.

${ }^{20}$ It must be noted that defining $\mathrm{S}_{\mathrm{its}}$ as the difference between the state limit and $\mathrm{M}_{\mathrm{its}}$ does not take into account the fact that states may allow exemptions that temporarily stop the clock for some welfare recipients. In this case, welfare participation occurs without depleting the stock of remaining months of eligibility. Even if states define broad categories to which exemptions can be applied, there are at least two reasons why it is not feasible to include this information in defining $S_{\text {its. }}$. First, many categories are based on factors that the researcher cannot observe (such as being a victim of domestic violence, disability status, caring for a disabled family member). Second, welfare workers have large discretion in granting exemptions to recipients who apply for them (Bloom et al. 2002). As a result, we can only
} 
October 2000-December 2003 and October 2003-December 2006), we impute $\mathrm{M}_{\mathrm{its}}$ as of the calendar month that corresponds to the first time individual $\mathrm{i}$ is interviewed $\left(\mathrm{M}^{0}{ }_{\mathrm{i}}\right)$ on the base of (i) information from retrospective questions asked at the beginning of each panel, (ii) a fitted model for $\mathrm{M}_{\mathrm{its}}$ as of the last wave of the previous panel, and (iii) administrative data. We then impute the months of eligibility left in one's clock as of the beginning of the panel as $\mathrm{S}_{\mathrm{i}}^{0}=\mathrm{N}_{\mathrm{s}}$ $\mathrm{M}_{\mathrm{i}}^{0}$. For later months, we update this variable based on in-sample information, that is, $\mathrm{S}_{\mathrm{it}}=\mathrm{S}_{\mathrm{i}}^{0}$ - (months of welfare use from the $1^{\text {st }}$ interview until $\left.\mathrm{t}-1\right)$.

Specifically, to impute $\mathrm{M}_{\mathrm{i}}^{0}$ as of the beginning of the 2001 and 2004 panels we fit the following model:

$$
\mathrm{M}_{\text {its }}=\phi_{1}^{\mathrm{p}}+\phi_{2}^{\mathrm{p}} \mathrm{X}_{\text {its }}+\phi_{2}^{\mathrm{p}} \mathrm{W}_{\mathrm{i}}+\eta^{\mathrm{p}}{ }_{\mathrm{s}}+\varepsilon_{\text {its }}=\phi^{\mathrm{p}} \mathbf{Y}_{\text {its }} \quad \text { if } \mathrm{W}_{\mathrm{i}}>0
$$

for individual-month observations as of the last interview (fourth reference month of the last wave) of panel $p=1996,2001$. We then use the estimated coefficients $\phi^{\mathrm{p}}$ to predict $\mathrm{M}^{0}{ }_{\mathrm{i}}$ as of the first interview (first reference month of wave 1) of panel 2001 and 2004, respectively. The prediction is based on a set of observable socio-demographic characteristics $\left(\mathrm{X}_{\mathrm{i}}\right.$, including age, education and number of children), state dummies $\left(\eta_{\mathrm{s}}\right)$ and the number of months of welfare experience $\left(\mathrm{W}_{\mathrm{i}}\right)$, which is gathered from in-sample information (at the end of the 1996 panel), information in the recipiency module (at the beginning of the 2001 and 2004 panels) or both (at the end of the 2001 panel). We use model (3) to forecast $\mathrm{M}^{0}{ }_{\mathrm{i}}$ at the beginning of panel 2001

define $S_{\text {its }}$ abstracting from the existence of exemptions, and test for the extent to which they were eventually granted by estimating the relationship between having exhausted benefits $\left(S_{\text {its }} \leq 0\right)$ and the probability of welfare use in month $t$. The limitation of this approach is that it does not allow to separately identify the extent of exemptions and extensions. 
and 2004 only for those individuals with previous welfare experience $\left(\mathrm{W}_{\mathrm{i}}>0\right)$. For individuals who have never been on welfare before, we set $\mathrm{M}^{0}=0$.

We also use administrative data to improve our imputation of $\mathrm{M}^{0}$ as of the beginning of panel 2001 and 2004. In particular, we forecast $\mathrm{M}^{0}{ }_{\mathrm{i}}$ not only using the estimated coefficients from model (3), but also including constraints implied by administrative counts of welfare cases. In practice, the procedure consists in framing the model as an overidentified moment restriction problem, and estimating it through the Generalized Method of Moments (GMM). The first restriction is the usual orthogonality condition for Least Squares estimates. The second restriction is that the weighted sum of the predicted values must equal the cumulative counts since time limit implementation from the administrative data, net of an undercount of 1 million single-parent cases per month (estimated from the data plotted in Figure 2).

\section{Summary Statistics}

Table 3 reports summary statistics of the policy and economic variables (by year) included in the analysis. After peaking at 33 percent in 1993, the yearly average welfare participation rate across states drops slightly in 1994 and 1995, plummets to 25 percent in 1996, then continues falling steadily to reach 8 percent in 2002 and plateaus at this level through 2006 . The sample period includes two economic downturns, captured by rising unemployment rates both in the early 1990s and in the early 2000s. In the period of analysis we also observe a significant erosion of the real value of the AFDC/TANF maximum guarantee and a sizable increase in the generosity of EITC maximum credits. State activity in experimenting with reforms of the AFDC program picks in 1995, when almost half of our sample is subject to some kind of waiver policy. The TANF federal rules, approved in August 1996, are 
implemented by states between September 1996 and January 1998. As regards time limit policies, all states but Michigan and Vermont implemented them by July 1998. Individuals living in Vermont are dropped from the analysis, since this state was not separately identified in SIPP until the 2004 panel. Since Michigan placed no time limit on benefits through 2006, the fraction of individual-month observations not facing any time limit policy from 1999 on corresponds to the population in this state.

Table 3 also reports the share of the sample facing non-binding limits $(\mathrm{S} \geq \mathrm{H})$, the share that is entitled to fewer months of eligibility than their eligibility horizon $(0<\mathrm{S}<\mathrm{H})$ and the share that has already hit the limit $(\mathrm{S} \leq 0)$. Notably, the latter increases over time from 1.3 percent in 1999 to 5.5 percent in 2006 . There is evidence of a drop in 2004, which may at least partly be spurious to pooling data from two consecutive panels (the 2001 panel spans the period through December 2003, and the 2004 panel the period since October 2003). Both forecasting pre-panel welfare use as in Equation (3) and constraining the estimates to match the cumulative welfare caseloads from administrative data are found to shrink the discontinuity between panels, but there remains the concern that seam bias may be an issue here. ${ }^{21}$

Table 4 provides summary statistics of family level characteristics, both in the full sample of families headed by single mothers aged between 16 and 55 (column 1), and separately for families who either do not face time limit policies (column 2), or, if they do, perceive more or

\footnotetext{
${ }^{21}$ On the other hand, since the population of single mothers may change over time (some women exit the pool - when their youngest child turns 18 - and others enter it - at the time of their first out-ofwedlock birth), the share of the sample hitting the limit may indeed decrease over time. However, the very sharp discontinuity in the series observed in 2004 when comparing within-panel estimates (and using only information provided in the recipiency history module to recover $\mathrm{S}_{0}$ ) suggests that seaming plays a role.
} 
less binding constraints (columns 3 through 5). First, we notice some relevant differences in the socio-demographic characteristics across columns. Relative to the group of women not facing any time limit policy, single mothers who have used up all of their months of eligibility $(\mathrm{S} \leq 0)$ are less likely to have ever been married or to hold a high school diploma or higher, and are more likely to be black and to have more and younger children. On the contrary, women who have a positive number of months of eligibility left $(S>0)$ tend to be more educated and non-Hispanic. Among them, there are sizable differences between women who face binding time limits $(\mathrm{S}<\mathrm{H})$ and those who don't $(\mathrm{S} \geq \mathrm{H})$. First of all, the latter have older children $(13$ or older) - a fact that arises mechanically from defining the eligibility horizon $\mathrm{H}$ as the number of months until the youngest child turns $18 .^{22}$ Women in this group do not only have older children; they are older too, as well as more likely to be divorced. In addition, they have higher rates of college attendance and are significantly more likely to be white. The fact that this group of women has different socio-demographic characteristics relative to the one not facing time limits raises concerns on whether comparing the two can serve as a test for the "unconstrained hypothesis." The differences also show the importance to specify (as we do) a flexible model where the effects of policy factors other than time limits, as well as of timevarying economic factors, are allowed to vary by socio-demographic characteristics.

Table 4 also reports the means of the outcome variables of interest. Among those women who hit the limit $(\mathrm{S} \leq 0)$, it is noticeable that 44 percent still receive income from welfare suggesting that exemptions and extensions are widespread. However, this figure alone cannot

\footnotetext{
${ }^{22}$ As opposed to the approach in GM and Grogger $(2002,2003,2004)$, however, the child's age cutoff can here be higher than 13, depending on the time limit imposed by the state $\left(\mathrm{N}_{\mathrm{s}}\right)$ and the number of months on welfare use accumulated by the family.
} 
be taken as evidence that time limits have not at all been enforced. First, the average monthly transfer received by this group is lower than for women not facing the limit: this may partly arise from the erosion of AFDC/TANF benefits in real terms over time (see Table 3), but is also consistent with binding "reduction" time limit policies. Second, we would expect families who have hit the limit to face unobservable barriers to work that not only made them more likely to use welfare in the past, but also more likely to be granted an exception. This is confirmed by a perusal of the other outcomes of these families. Both employment rates and earnings (if positive) are significantly lower than average, suggesting that women in this group not only face barriers that prevent them from working, but may also have very scarce skills that erode the returns they earn from work. Not surprisingly, this group has also high participation rates in other means-tested programs, such as SSI and Food Stamps, and very high rates of poverty and deep poverty. Because of the endogeneity between the likelihood to be granted an exception and unobservable characteristics that may directly affect the outcome of interest, in the next section we attempt to learn about the effects of time limit by first forming a prediction for hitting the limit that is based on observable (policy and family) characteristics, and then identifying the extent and the effects of enforcement for those who comply with this prediction.

\section{Estimation Results}

\section{Welfare use}

Regression results of the effects of time limits on welfare use and TANF benefits appear in

Table 6. We only report the coefficients of the three time limit variables in Equation (1), but 
all specifications include controls for socio-demographic characteristics ${ }^{23}$ and state-level policy and economic factors; state and year dummies; state-specific linear and quadratic trends; interactions between economic and policy variables and the age of the youngest and the oldest child, and the number of children, mother's education, and their interaction. Standard errors are adjusted to allow heteroskedasticity and correlation across families living in the same state. ${ }^{24}$

The importance of using only exogenous variation in the remaining stock of benefits $\mathrm{S}_{\text {its }}$ is emphasized by the differences between OLS and IV estimates. First, as opposed to the OLS estimates (column 1), the IV results (column 2) support time limit enforcement, and are also consistent with the main prediction of a dynamic model of welfare use on the existence of banking effects: women facing incomplete coverage under time limits $(0<\mathrm{S}<\mathrm{H})$ participate in welfare less than in the absence of this policy. Noticeably, though, enforcement effects are economically more significant than banking effects. Also, as we would expect, the difference between probability of welfare use across women not facing the policy and women unconstrained under time limits $(\mathrm{S} \geq \mathrm{H})$ is not statistically significant.

The dependent variable in columns 3 and 4 is the monthly dollar amount of family income from AFDC/TANF. Like the results for welfare use, the IV estimates are consistent with time

\footnotetext{
${ }^{23}$ Mother's age (linear and quadratic); dummies for marital status (never married, separated, divorced or widow), race (white, black, Asian), Hispanic origin, foreign-born status and education (less than $7^{\text {th }}$ grade, $7^{\text {th }}$ to $8^{\text {th }}$ grade, $9^{\text {th }}$ grade, $10^{\text {th }}$ grade, $11^{\text {th }}$ grade, high-school degree, at least some college education); number of children less than 6 , between 6 and 12, and older than 12; dummies for the age of the youngest and oldest child (less than 3 years old, between 3 and 5, between 6 and 12, older than 12).

${ }^{24}$ Given that there are repeated observations for the same individual, standard errors should be clustered at the individual level as well. Since this is nested in the state clustering, we opt for clustering at the higher level (Bertrand, Duflo and Mullainathan, 2004).
} 
limit enforcement. On average, having hit the limit decreases benefits by around $\$ 250$. On the contrary, both unconstrained women and those facing incomplete coverage do not experience economically significant changes in their welfare transfers.

As discussed in Section II, states have used their flexibility under the federal law to adopt a wide variety of time limits that differ not only in length, but also in other ways. In our empirical exercise, the state time limit $\mathrm{N}_{\mathrm{s}}$ corresponds to the most binding time limit imposed in the state (that is, the intermittent time limit if in place) and no distinction has been made so far between reduction and termination limits. Table 7 reports IV estimation results of the effects of time limits on welfare use separately run for families living in states with different time limit policies. As expected, we find evidence of enforcement only in the subsample of individuals facing termination limits (column 1), while families hitting a reduction limit continue to receive benefits at higher rates than families not facing the policy (column 2). We also find evidence that the mechanical caseload reduction due to this policy only arises in states that imposed lifetime or intermittent limits shorter than 60 months (column 4), while in states implementing the standard 60-month lifetime limit individual welfare use is affected only, if any, through behavioral effects (column 3).

\section{Employment and Earnings}

The IV estimation results on the effects of time limits suggest that this policy did reduce welfare use and welfare benefits, because single mothers were dropped from the rolls and, even if at a smaller extent, also because some of them started to decrease welfare use before hitting the limit. But did employment for these women increase? Table 8 reports regression results for the effects of time limits on the family head's labor force status (whether employed at any time 
during the month, or whether out of the labor force) and earnings from work (in levels and in logs). The estimates suggest that women in families that have hit the limit increase their employment by 21 percentage points — a sizable effect (column 1). The corresponding negative effect in column 2 indicates that women entering the labor force explain the increase in employment. However, earnings for women hitting the limit do not increase on average, neither when incorporating the work-no-work decision (column 3), nor when studying the effects on women that already had some labor earnings (column 4). The results are consistent with earnings for women previously out of the labor force being lower than average, but also with poorer matches (lower paying jobs) for women motivated to accept jobs (that they may have not accepted otherwise) in response to their benefits being cut.

As regards women facing incomplete coverage, there is evidence of increased employment and also increased earnings - consistent with women taking up jobs more frequently when they know the clock is running, and in particular jobs that are better than average matches.

\section{Other transfers from social programs}

Table 9 reports estimation results for family's participation in other government programs, that is, Food Stamps and Supplemental Security Income. Several papers have looked at the impact of welfare reform on programs other than AFDC/TANF. For example, Danielson and Klerman (2006) find that welfare reform was correlated with the drop in food stamp caseloads in the mid-1990s. On the contrary, Schmidt and Sevak (2004) provide evidence of shifting from AFDC/TANF to SSI, with female-headed households in states aggressively pursuing welfare reform in more recent years more likely to have SSI income. 
As shown in Table 9, we find that hitting the limit is not only associated with being cut from TANF benefits, but also with a decrease in transfers from other programs. As regards Food Stamps, there is both a sizable drop in the probability to participate in the program and in the monetary value of the transfer (which decreases by almost $\$ 50$ per month). As regards SSI, even if the drop in use is not statistically significant, we find evidence of a drop in the dollar amount received of almost $\$ 80$ per month. These findings seem to suggest that being dropped from TANF is correlated with losing access to other programs too, raising the concern about the ability of low-income families dropped from the rolls to maintain themselves.

The probability to receive SSI or food stamps decreases as well for women facing incomplete coverage. However, the magnitude of these changes is negligible compared to the case when time limits bite.

\section{Poverty, household income and living arrangements}

The concern that families hitting the limit and likely to be dropped from the rolls may be struggling financially is supported by evidence of an increase in their likelihood to be living in poverty, especially in deep poverty (columns 1 and 2, Table 10). However, there is no evidence of a significant decrease in household income (column 3). This finding, together with evidence that hitting the limit is associated with an increase in the probability that another adult, beyond the single mother head, is living in the household (column 4), suggests that doubling up may be a way for families who timed out of welfare to respond to the need of greater income sharing. 
As opposed to the case when time limits bite, poverty rates are found to decrease among families facing incomplete coverage - suggesting that, if indeed the ticking clock moved these families out of welfare and into work, this also lifted them out of poverty.

\section{Conclusions}

Since the reforms of the 1990s overhauled the U.S. welfare system, a large amount of research has tried to evaluate the various effects of the new rules on the behavior and wellbeing of low-income families. Yet, it is striking how many questions about the effects of these policy changes remain unanswered (Blank 2007a). This paper is aimed at increasing our understanding of the effects of the introduction of time limits on welfare receipt, one of the changes we know the least about - largely because of data limitations. In fact, we have very limited information even on the ways in which this policy is actually being implemented by states. Closely related to the issue of how states are utilizing time limits is the raising concern about "disconnected" women, that is, that growing segment of single mothers who report themselves as neither working nor on welfare (Turner, Danziger and Seefeldt 2006; Blank 2007b; Blank and Kovak 2009).

In this paper, for female-headed families who are predicted to have hit the limit, we find evidence of enforcement of the policy (which causes monthly income from welfare to drop by an average of $\$ 250$ ), as well as evidence of sizable increases in the likelihood that the mother works at some point during the reference month. Despite the increased likelihood of entering the labor force, however, the loss of income from welfare is not offset by increases in other income sources: not only there is no significant change in earnings, but also income from other transfer programs (such as SSI and Food Stamps) decreases - resulting in increasing rates of 
deep poverty among these families. Analyses at the household level, however, show that there is no drop in household income, probably because families are doubling up as a response to the need of more income sharing.

Time limits were designed to create strong incentives for women to seek work and leave welfare. Some evidence that the policy promoted families' transition from welfare to work without increasing their material hardship is indeed provided in this paper as regards cases when the limit does not bite, that is, for families who are allegedly leaving the rolls because of "banking" incentives. Our findings for families hitting the limit, however, underscore the importance of more research on the ways states are implementing time limits, and on whether and how states are effectively identifying needy families that should be shielded from the penalties. Specifically, it would be crucial to assess whether states find ways to assist women who are forced off TANF to continue using the services still available to themselves and their children. To this regard, more work to understand the interaction between government programs after welfare reform is clearly warranted. 


\section{References}

Bertrand, Marianne, Esther Duflo and Sendhil Mullainathan. 2004. How Much Should we Trust Differences-in-Differences Estimates? Quarterly Journal of Economics, 119(1): 249-275.

Bitler, Marianne P., Jonah B. Gelbach and Hilary W. Hoynes. 2006. "What Mean Impacts Miss: Distributional Effects Of Welfare Reform Experiments," American Economic Review, 96(4): 988-1012.

Blank, Rebecca and Patricia Ruggles. 1996. When Do Women Use Aid to Families with Dependent Children and Food Stamps? The Dynamics of Eligibility versus Participation. Journal of Human Resources 31(1): 57-89.

Blank, Rebecca. 2002. Evaluating Welfare Reform in the United States. Journal of Economic Literature 40: 1105-1166.

Blank, Rebecca. 2007a. "What We Know, What We Don't Know, and What We Need to Know about Welfare Reform.” NPC working paper 2007-19, University of Michigan.

Blank, Rebecca. 2007b. "Improving the Safety Net for Single Mothers Who Face Serious Barriers to Work." Future of Children, 17(2): 183-97

Blank, Rebecca and Brian Kovak. 2009. "The Growing Problem of Disconnected Single Mothers" In Making the Work-Based Safety Net Work Better, Carolyn J. Heinrich and John Karl Scholz, eds. New York: Russell Sage Press.

Bloom, Dan, Mary Farrell, Barbara Fink, and Diana Adams-Ciardullo. 2002. Welfare Time Limits: State Policies, Implementation, and Effects on Families. Washington, D.C.: U.S. Department of Health and Human Services.

Card, David, Andrew Hildreth and Lara Shore-Sheppard. 2004. "The Measurement of Medicaid Coverage in the SIPP: Evidence From a Comparison of Matched Records." Journal of Business and Economics Statistics, 22(4): 410-420.

Chay, Kenneth, Hilary Hoynes, and Dean Hyslop. 1999. “A Non-Experimental Analysis of 'True' State Dependence in Monthly Welfare Participation Sequences.” American Statistical Association, 1999 Proceedings of the Business and Economic Statistics Section, 9-17. 
Council of Economic Advisers. 1997. Technical Report: Explaining the Decline in Welfare Receipt 1993-1996. Washington D.C.: Council of Economic Advisers.

Council of Economic Advisers. 1999. Technical Report: The Effects of Welfare Policy and the Economic Expansion on Welfare Caseloads: An Update. Washington D.C.: Council of Economic Advisers.

Currie, Janet and Nancy Cole. 1993. "Welfare and Child Health: The Link Between AFDC Participation and Birth Weight." The American Economic Review, 83: 971-985.

Danielson, Caroline and Jacob Alex Klerman. 2006. "Why Did the Food Stamp Caseload Decline (and Rise)? Effects of Policies and the Economy.” Institute for Research on Poverty Discussion Paper \#1316-06. Madison, WI: IRP.

Duncan, Gregory, Kathleen Mullan Harris, and Johanne Boisjoly. 2000. "Time Limits and Welfare Reform: New Estimates of the Number and Characteristics of Affected Families," Social Service Review, 74: 55-75.

Fang, Hanming and Michael Keane. 2004. "Assessing the Impact of Welfare Reform on Single Mothers.” Brookings Papers on Economic Activity, 1: 1-116.

Farrell, Mary, Sarah Rich, Lesley Turner, David Seith and Dan Bloom. 2008. Welfare Time Limits: An Update of State Policies, Implementation, and Effects on Families. The Lewin Group and MDRC.

Grogger, Jeffrey. 2002. "The Behavioral Effects of Welfare Time Limits.” American Economic Review 92: 385-389.

Grogger, Jeffrey. 2003. "The Effects of the EITC, Time Limits, and Other Policy Changes on Welfare Use, Work, and Income among Female-Headed Families.” Review of Economics and Statistics, 85: 394-408.

Grogger, Jeffrey. 2004. “Time Limits and Welfare Use.” Journal of Human Resources, 39 (2): $405-424$.

Grogger, Jeffrey, Lynn Karolyn, and Jacob Klerman. 2002. Consequences of Welfare Reform: A Research Synthesis. Santa Monica, CA: RAND.

Grogger, Jeffrey and Charles Michalopoulos. 2003. "Welfare Dynamics under Time Limits." Journal of Political Economy, 111: 530-554.

Gruber, Jonathan. 2000. "Cash Welfare As A Consumption Smoothing Mechanism For 
Divorced Mothers." Journal of Public Economics 75: 157-182.

Jabine, Thomas, King Karen and Petroni Rita. 1990. "Measurement Error”, in SIPP Quality Profile, Washington, DC: United States Department of Commerce Bureau of the Census.

Leonard Jonathan S. and Alex Mas. 2005. "Welfare Reform, Time-Limits, and Infant Mortality", mimeo, University of California Berkeley.

Meyer, Bruce and James Sullivan. 2008. "Changes in the Consumption, Income and WellBeing of Single Mother Headed Families.” American Economic Review, 98(5): 22212241.

Mazzolari, Francesca. 2007. "Welfare Use When Approaching the Time Limit." Journal of Human Resources. 42(3): 596-618.

Moffitt, Robert. 1983. “An Economic Model of Welfare Stigma.” American Economic Review, 73(5): 1023-1035.

Moffitt, Robert. 1999. "The Effect of Pre-PRWORA Waivers on AFDC Caseloads and Female Earnings, Income, and Labor Force Behavior.” In Economic Conditions and Welfare Reform, ed. Sheldon H. Danziger, 91-118. Kalamazoo, MI: Upjohn Institute Press.

Moffitt, Robert. 2003. “The Temporary Assistance for Needy Families Program.” In Means Tested Transfer Programs in the United States, ed. Robert Moffitt. Chicago, MA: University of Chicago Press.

Pavetti LaDonna A. and Jacqueline Kauff. 2006. "When Five Years is Not Enough: Identifying and Addressing the Needs of Families Nearing the TANF Time Limit in Ramsey County, Minnesota.” Lessons from the Field series. Princeton, NJ: Mathematica Policy Research.

Schmidt, Lucie and Purvi Sevak. 2004. “AFDC, SSI, and Welfare Reform Aggressiveness: Caseload Reductions vs. Caseload Shifting." Journal of Human Resources, 39(3): 792812.

Schoeni, Robert and Rebecca Blank. 2000. "What Has Welfare Reform Accomplished? Impacts on Welfare Participation, Employment, Income, Poverty and Family Structure," Working Paper No. 7627. Cambridge, MA: National Bureau of Economic Research.

Staiger Douglas and James Stock. 1997. "Instrumental Variables Regression with Weak 
Instruments." Econometrica, 65: 557-586.

Swann, Christopher. 2005. "Welfare Reform when Recipients are Forward-Looking." Journal of Human Resources, 40(1): 31-56.

Turner, Lesley, Sheldon Danziger, and Kristin Seefeldt. 2006. "Failing the Transition from Welfare to Work: Women Chronically Disconnected from Employment and Cash Welfare." Social Science Quarterly, 87(2): 227-49.

Zedlewski, Sheila and Jennifer Holland. 2003. "How Much Do Welfare Recipients Know about Time Limits?” Snapshots of America's Families III No.15. Washington, D.C.: Urban Institute.

Ziliak, James, David Figlio, Elizabeth Davis, and Laura Connolly. 2000. "Accounting for the Decline in AFDC Caseloads: Welfare Reform or the Economy?” Journal of Human Resources, 35(3): 570-586. 
Table 1: Features of State Time Limit Policies and

Date of Implementation of Major Statewide Waivers, TANF Programs and Time Limits

\begin{tabular}{|c|c|c|c|c|c|c|c|c|c|c|}
\hline \multirow[b]{2}{*}{ State } & \multicolumn{2}{|c|}{ Lifetime Limit } & \multicolumn{2}{|c|}{ Intermittent Time Limit } & \multirow[b]{2}{*}{$\begin{array}{l}\text { most binding } \\
\text { TL (months) }\end{array}$} & \multirow[b]{2}{*}{$\begin{array}{c}\text { reduction } \\
\text { TL [i] }\end{array}$} & \multicolumn{3}{|c|}{ Implementation } & \multirow[b]{2}{*}{$\begin{array}{l}\text { Date Families first } \\
\text { Exceed(ed) limit [iv] }\end{array}$} \\
\hline & & $\begin{array}{l}\text { duration } \\
\text { (months) }\end{array}$ & in place & duration (months) & & & waiver [ii] & TANF & TL [iii] & \\
\hline Alabama & 1 & 60 & 0 & & 60 & 0 & & Nov-96 & Nov-96 & Nov-01 \\
\hline Alaska & 1 & 60 & 0 & & 60 & 0 & & Jul-97 & Jul-97 & Jul-02 \\
\hline Arizona & 0 & none & 1 & 24 in 60 & 24 & 1 & Nov-95 & Oct-96 & Nov-95 & Nov-97 \\
\hline Arkansas & 1 & 24 & 0 & & 24 & 0 & Jul-94 & Jul-97 & Jul-98 & Jul-00 \\
\hline California & 1 & 60 & 0 & & 60 & 1 & Dec-92 & Jan-98 & Jan-98 & Jan-03 \\
\hline Colorado & 1 & 60 & 0 & & 60 & 0 & & Jul-97 & Jul-97 & Jul-02 \\
\hline Connecticut [a] & 1 & 21 & 1 & & 21 & 0 & Jan-96 & Oct-96 & Jan-96 & Oct-97 \\
\hline Delaware [a] & 1 & 60 & 1 & 48 ineligible for 96 & 48 & 0 & Oct-95 [2] & Mar-97 & Mar-97 & Oct-99 \\
\hline $\mathrm{DC}$ & 1 & 60 & 0 & & 60 & 0 & & Mar-97 & Mar-97 & Oct-98 \\
\hline Florida [a] & 1 & 48 & 1 & 36 in 72 & 24 & 0 & Jun-96 & Oct-96 & Oct-96 & Oct-98 \\
\hline Florida [b] & 1 & 48 & 1 & 24 in 60 & 36 & 0 & & & & \\
\hline Georgia & 1 & 48 & 0 & & 48 & 0 & Jan-94 & Jan-97 & Jan-97 & Jan-01 \\
\hline Hawaii & 1 & 60 & 0 & & 60 & 0 & Feb-97 & Jun-97 & Dec-96 & Dec-01 \\
\hline Idaho & 1 & 24 & 0 & & 24 & 0 & Aug-96 & Jul-97 & Jul-97 & Jul-99 \\
\hline Illinois & 1 & 60 & 0 & & 60 & 0 & Nov-93 & Jul-97 & Jul-97 & Jul-02 \\
\hline Indiana & 1 & 24 & 0 & & 24 & 1 & May-95 [3] & Oct-96 & May-97 & Jul-97 \\
\hline Iowa & 1 & 60 & 0 & & 60 & 0 & Oct- 93 & Jan-97 & Jan-97 & Jan-02 \\
\hline Kansas & 1 & 60 & 0 & & 60 & 0 & & Oct-96 & Oct-96 & Oct-01 \\
\hline Kentucky & 1 & 60 & 0 & & 60 & 0 & & Oct-96 & Oct-96 & Oct-01 \\
\hline Louisiana & 1 & 60 & 1 & 24 in 60 & 24 & 0 & & Jan-97 & Jan-97 & Jan-99 \\
\hline Maine & 1 & 60 & 0 & & 60 & 1 & Jun-96 & Nov-96 & Nov-96 & Nov-01 \\
\hline Maryland & 1 & 60 & 0 & & 60 & 1 & Mar-96 & Dec-96 & Jan-97 & Jan-02 \\
\hline Massachusetts & 0 & none & 1 & 24 in 60 & 24 & 0 & Nov-95 & Sep-96 & Dec-96 & Dec-98 \\
\hline Michigan & 0 & none & 0 & & . & & Oct-92 & Sep-96 & ---- & ---- \\
\hline Minnesota & 1 & 60 & 0 & & 60 & 0 & & Jul-97 & Jul-97 & Jul-02 \\
\hline Mississippi & 1 & 60 & 0 & & 60 & 0 & Oct-95 & Jul-97 & Oct-96 & Oct-01 \\
\hline Missouri & 1 & 60 & 0 & & 60 & 0 & Jun-95 & Dec-96 & Jul-97 & Jul-02 \\
\hline Montana & 1 & 60 & 0 & & 60 & 0 & Feb-96 & Feb-97 & Feb-97 & Feb-02 \\
\hline Nebraska & 1 & 48 & 1 & 24 in 48 & 24 & 0 & Oct-95 & Dec-96 & Dec-96 & Dec-98 \\
\hline Nevada & 1 & 60 & 1 & 24 ineligible for 12 & 24 & 0 & & Dec-96 & Jan-98 & Jan- 00 \\
\hline New Hampshire & 1 & 60 & 0 & & 60 & 0 & Jun-96 & Oct-96 & Oct-96 & Oct-01 \\
\hline New Jersey & 1 & 60 & 0 & & 60 & 0 & Oct-92 & Jul-97 & Apr-97 & Apr-02 \\
\hline New Mexico & 1 & 60 & 0 & & 60 & 0 & & Jul-97 [6] & Jul-97 & Jul-02 \\
\hline New York & 0 & $60[1]$ & 0 & & 60 & 1 & & Nov-97 & Dec-96 & Dec-01 \\
\hline North Carolina & 1 & 60 & 1 & 24 ineligible for 36 & 24 & 0 & Jul-96 & Jan-97 & Aug-96 & Aug-98 \\
\hline North Dakota & 1 & 60 & 0 & & 60 & 0 & & Jul-97 & Jul-97 & Jul-02 \\
\hline Ohio & 1 & 60 & 1 & 36 ineligible for 24 & 36 & 0 & Jul-96 & Oct-96 & Oct-97 & Oct- 00 \\
\hline Oklahoma & 1 & 60 & 0 & & 60 & 0 & & Oct-96 & Oct-96 & Oct-01 \\
\hline Oregon & 0 & none & 1 & 24 in 84 & 24 & 1 & Feb-93 & Oct-96 & Jul-96 & Jul-98 \\
\hline Pennsylvania & 1 & 60 & 0 & & 60 & 0 & & Mar-97 & Mar-97 & Mar-02 \\
\hline Rhode Island & 1 & 60 & 0 & & 60 & 1 & & May-97 & May-97 & May-02 \\
\hline South Carolina & 1 & 60 & 1 & 24 in 120 & 24 & 0 & May-96 & Oct-96 & Oct-96 & Oct-98 \\
\hline South Dakota & 1 & 60 & 0 & & 60 & 0 & Jun-94 & Dec-96 & Dec-96 & Dec-01 \\
\hline Tennessee & 1 & 60 & 1 & 18 ineligible for 3 & 18 & 0 & Sep-96 & Oct-96 & Oct-96 & Apr-98 \\
\hline Texas [a] & 1 & 60 & 1 & 12 ineligible for 60 & 12 & 0 & Jun-96 [4] & Nov-96 & Sep-97 & Sep-98 \\
\hline Texas [b] & 1 & 60 & 1 & 24 ineligible for 60 & 24 & 0 & $"$ & $"$ & $"$ & Sep-98 \\
\hline Texas $[\mathrm{c}]$ & 1 & 60 & 1 & 36 ineligible for 60 & 36 & 0 & $"$ & $"$ & $"$ & Sep-98 \\
\hline Utah & 1 & 36 & 0 & & 36 & 0 & Jan-93 & Oct-96 & Jan-97 & Jan-00 \\
\hline Vermont & 0 & none & 0 & & . & & Jul-94 & Sep-96 & --- & ---- \\
\hline Virginia & 1 & 60 & 1 & 24 ineligible for 24 & 24 & 0 & Jul-95 [5] & Feb-97 & Oct-97 & Oct-99 \\
\hline Washington & 1 & 60 & 0 & & 60 & 0 & Jan-96 & Jan-97 & Aug-97 & Aug-02 \\
\hline West Virginia & 1 & 60 & 0 & & 60 & 0 & & Jan-97 & Jan-97 & Jan-02 \\
\hline Wisconsin & 1 & 60 & 0 & & 60 & 0 & Jan-96 & Sep-97 & Oct-96 & Oct-01 \\
\hline Wyoming & 1 & 60 & 0 & & 60 & 0 & & Jan-97 & Jan-97 & Jan-02 \\
\hline
\end{tabular}

Notes: [i] A reduction time limit (as opposed to the general case of termination time limit) means that the child portion of the welfare benefit continues after time limits exhaustion. [ii] Implementation of major statewide waivers.

[iii] Effective date for time limits (actual counting date for statewide time limits)

[iv] Denotes the month following the date families could potentially accumulate the maximum number of months of TANF assistance.

Connecticut [a]: In Oct 2001 CT imposed a new 60-month time limit that allows fewer exceptions than the previous 21-month limit, and that counts benefits received since Oct 1996. Delaware [a]: In Januray 2000, Delaware introduced a new 36-month lifetime limit.

Florida [a] applies to women with age under 24 and who did not finish high school. Florida [b] applies to other women.

TX [a] applies to women with at least a high school diploma. TX [b] applies to women who completed 3 or more years of high school but do not hold a HS diploma. TX [c] others

[1] New York state allows those reaching a 60-month limit to transition to a state funded Safety Net Program that provides the same benefits but only partly (20\%) in cash.

[2] Delaware began implementation of its termination time limit with a small number of cases in October 1995; the policy became universal in March 1997.

[3] IN began implementation of 24-month time limit policy for "job-ready" non-exempt cases in July 95; beginning May 97 the 24-month limit was expanded to all non-exempt cases.

[4] Texas' 12, 24, or 36 month time limit began in one county in June 1996 and was expanded to the entire state by September 1997.

[5] Virginia's termination time limit began in five counties in July 1995 and was expanded to the entire state by October 1997.

[6] New Mexico implemented TANF again in 1998 after its first 1997 plan was ruled unconstitutional.

Sources: CEA (1999), Bloom et al. (2002), Bitler et al. (2004), ASPE webpage (http://aspe.hhs.gov/hsp/waiver-Policies99/W1tim_limt.htm\#N5) 
Table 2: Correlation between underreporting of welfare use in SIPP and time limit implementation

\begin{tabular}{lll} 
(1) & $(2)$ & $(3)$ \\
bivariate model & $\begin{array}{l}\text { state fixed } \\
\text { effects }\end{array}$ & $\begin{array}{l}\text { state and year } \\
\text { fixed effects }\end{array}$ \\
\hline
\end{tabular}

\section{A. All Welfare cases}

TL implementation $\mathrm{I}\left(\mathrm{t} \geq \overline{\mathrm{T}}_{\mathrm{s}}\right)$

$-8,311.9 * * *$
$(752.2)$
$24,978.9 * * *$
$(555.5)$
8,400
0.01

$-8,165.9 * * *$

$-2,562.7 *$

Constant

Observations

0.01

(441.1)

$(1,412.0)$

$13,044.4 * * * \quad 11,038.7 * * *$

$(1,422.6)$

$(2,214.9)$

R-squared

8,400

8,400

\section{B. Single-parent cases}

TL implementation $\mathrm{I}\left(\mathrm{t} \geq \overline{\mathrm{T}}_{\mathrm{s}}\right)$

$-15,368.4 * * *$
$(1,055.6)$
$41,839.2 * * *$
$(779.6)$
8,400

0.67

0.68

\section{Constant}

Observations

0.02

$\begin{array}{ll}-14,293.8 * * * & -4,059.8 * * * \\ (413.5) & (1,290.4) \\ 23,332.9 * * * & 13,629.1 * * * \\ (1,333.7) & (2,024.2) \\ 8,400 & 8,400 \\ 0.86 & 0.87\end{array}$

Note: The dependent variable is the difference between administrative counts and SIPP-based estimates of welfare cases by state and month, from October 1989 to December 2006, in the 42 states separately identified in SIPP. 
Table 3: Summary statistics of policy and economic variables

\begin{tabular}{|c|c|c|c|c|c|c|c|c|c|c|}
\hline \multirow[b]{2}{*}{ Year } & \multirow[b]{2}{*}{$\begin{array}{c}\text { Welfare } \\
\text { use }\end{array}$} & \multirow[b]{2}{*}{$\begin{array}{l}\text { Unemp. } \\
\text { rate }\end{array}$} & \multirow[b]{2}{*}{$\begin{array}{c}\text { Max } \\
\text { welfare } \\
\text { benefit }\end{array}$} & \multirow[b]{2}{*}{$\begin{array}{c}\text { Max EITC } \\
\text { credit }\end{array}$} & \multicolumn{3}{|c|}{ Implementation } & \multicolumn{3}{|c|}{ Time limits } \\
\hline & & & & & Waiver & TANF & $\begin{array}{l}\text { Time } \\
\text { limits }\end{array}$ & $\begin{array}{c}\text { Not } \\
\text { Binding } \\
\mathrm{S} \geq \mathrm{H}\end{array}$ & $\begin{array}{c}\text { Banking } \\
0<\mathrm{S}<\mathrm{H}\end{array}$ & $\begin{array}{c}\text { Bite } \\
\mathrm{S} \leq 0\end{array}$ \\
\hline 1989 & $27.4 \%$ & 5.45 & $\$ 488$ & $\$ 1,152$ & 0 & 0 & 0 & 0 & 0 & 0 \\
\hline 1990 & $29.7 \%$ & 5.69 & $\$ 478$ & $\$ 1,148$ & 0 & 0 & 0 & 0 & 0 & 0 \\
\hline 1991 & $30.2 \%$ & 6.96 & $\$ 460$ & $\$ 1,395$ & 0 & 0 & 0 & 0 & 0 & 0 \\
\hline 1992 & $31.0 \%$ & 7.66 & $\$ 449$ & $\$ 1,521$ & $20.3 \%$ & 0 & 0 & 0 & 0 & 0 \\
\hline 1993 & $33.1 \%$ & 7.08 & $\$ 431$ & $\$ 1,602$ & $27.3 \%$ & 0 & 0 & 0 & 0 & 0 \\
\hline 1994 & $32.6 \%$ & 6.29 & $\$ 419$ & $\$ 2,417$ & $32.3 \%$ & 0 & 0 & 0 & 0 & 0 \\
\hline 1995 & $31.6 \%$ & 5.75 & $\$ 407$ & $\$ 2,734$ & $46.2 \%$ & 0 & 0 & 0 & 0 & 0 \\
\hline 1996 & $24.8 \%$ & 5.50 & $\$ 385$ & $\$ 2,836$ & $33.3 \%$ & $45.1 \%$ & $7.9 \%$ & $1.0 \%$ & $7.3 \%$ & $0.0 \%$ \\
\hline 1997 & $20.5 \%$ & 5.04 & $\$ 377$ & $\$ 2,868$ & $13.7 \%$ & $86.3 \%$ & $59.6 \%$ & $9.4 \%$ & $51.5 \%$ & $0.1 \%$ \\
\hline 1998 & $15.7 \%$ & 4.57 & $\$ 373$ & $\$ 2,910$ & 0 & $100 \%$ & $94.6 \%$ & $15.4 \%$ & $79.2 \%$ & $0.4 \%$ \\
\hline 1999 & $12.4 \%$ & 4.28 & $\$ 367$ & $\$ 2,898$ & 0 & $100 \%$ & $95.6 \%$ & $15.0 \%$ & $79.6 \%$ & $1.3 \%$ \\
\hline 2000 & $9.5 \%$ & 4.10 & $\$ 367$ & $\$ 2,835$ & 0 & $100 \%$ & $96.1 \%$ & $14.1 \%$ & $79.4 \%$ & $2.7 \%$ \\
\hline 2001 & $8.8 \%$ & 4.79 & $\$ 356$ & $\$ 2,859$ & 0 & $100 \%$ & $96.5 \%$ & $13.4 \%$ & $80.1 \%$ & $3.2 \%$ \\
\hline 2002 & $7.8 \%$ & 5.87 & $\$ 352$ & $\$ 2,911$ & 0 & $100 \%$ & $96.7 \%$ & $14.2 \%$ & $78.3 \%$ & $4.3 \%$ \\
\hline 2003 & $7.8 \%$ & 6.07 & $\$ 346$ & $\$ 2,915$ & 0 & $100 \%$ & $96.8 \%$ & $14.5 \%$ & $76.9 \%$ & $5.5 \%$ \\
\hline 2004 & $7.9 \%$ & 5.61 & $\$ 352$ & $\$ 2,893$ & 0 & $100 \%$ & $96.0 \%$ & $14.7 \%$ & $77.5 \%$ & $3.9 \%$ \\
\hline 2005 & $7.4 \%$ & 5.19 & $\$ 338$ & $\$ 2,867$ & 0 & $100 \%$ & $96.3 \%$ & $15.0 \%$ & $76.8 \%$ & $4.4 \%$ \\
\hline 2006 & $7.5 \%$ & 4.71 & $\$ 329$ & $\$ 2,874$ & 0 & $100 \%$ & $96.4 \%$ & $14.8 \%$ & $76.2 \%$ & $5.5 \%$ \\
\hline Total & $21.6 \%$ & 5.79 & $\$ 399$ & $\$ 2,387$ & $12.5 \%$ & $50.2 \%$ & $43.7 \%$ & $6.8 \%$ & $37.3 \%$ & $1.2 \%$ \\
\hline
\end{tabular}


Table 4: Summary statistics of individual and family level variables

\begin{tabular}{|c|c|c|c|c|c|}
\hline \multirow[b]{4}{*}{ Number of observations } & \multirow{4}{*}{$\begin{array}{r}\frac{\text { Full sample }}{} \\
544,234\end{array}$} & \multicolumn{4}{|c|}{ Time Limit Implementation } \\
\hline & & \multirow[t]{2}{*}{ No } & \multicolumn{3}{|c|}{ Yes } \\
\hline & & & $\begin{array}{l}\text { Binding } \\
\geq \mathrm{H}\end{array}$ & $\begin{array}{l}\text { Banking } \\
0<\mathrm{S}<\mathrm{H}\end{array}$ & $\begin{array}{l}\text { Bite } \\
\mathrm{S} \leq 0\end{array}$ \\
\hline & & 297,321 & 37,037 & 203,156 & 6,719 \\
\hline \multicolumn{6}{|l|}{ Single mother's characteristics } \\
\hline Age & 33.63 & 33.12 & 43.28 & 32.70 & 33.06 \\
\hline \multicolumn{6}{|c|}{ Marital status (excluded: never married) } \\
\hline Woman separated & $19.4 \%$ & $19.8 \%$ & $17.9 \%$ & $19.0 \%$ & $19.0 \%$ \\
\hline Woman widow & $4.3 \%$ & $4.7 \%$ & $8.7 \%$ & $2.9 \%$ & $0.9 \%$ \\
\hline Woman divorced & $37.1 \%$ & $37.4 \%$ & $58.8 \%$ & $33.2 \%$ & $20.5 \%$ \\
\hline \multicolumn{6}{|c|}{ Highest educational attainment (excluded: tenth grade or less) } \\
\hline Eleventh grade & $9.8 \%$ & $10.9 \%$ & $5.2 \%$ & $8.7 \%$ & $16.0 \%$ \\
\hline High School graduate & $37.8 \%$ & $40.3 \%$ & $32.0 \%$ & $35.1 \%$ & $30.4 \%$ \\
\hline At least some years of college & $38.7 \%$ & $33.6 \%$ & $53.5 \%$ & $44.4 \%$ & $26.6 \%$ \\
\hline \multicolumn{6}{|l|}{ Race and origin } \\
\hline Black & $33.9 \%$ & $34.8 \%$ & $25.3 \%$ & $33.8 \%$ & $47.1 \%$ \\
\hline Asian & $2.2 \%$ & $2.2 \%$ & $3.0 \%$ & $2.2 \%$ & $1.3 \%$ \\
\hline Hispanic & $24.1 \%$ & $29.7 \%$ & $13.0 \%$ & $17.4 \%$ & $24.3 \%$ \\
\hline Foreign-born & $11.9 \%$ & $12.8 \%$ & $11.0 \%$ & $10.7 \%$ & $11.6 \%$ \\
\hline \multicolumn{6}{|l|}{ Number of children } \\
\hline $0-5$ years old & 0.58 & 0.61 & 0.00 & 0.63 & 0.66 \\
\hline $6-12$ years old & 0.71 & 0.70 & 0.00 & 0.85 & 1.11 \\
\hline 13-17 years old & 0.49 & 0.48 & 1.31 & 0.36 & 0.58 \\
\hline Age of the youngest child & 7.16 & 6.95 & 15.33 & 6.00 & 6.66 \\
\hline Age of the oldest child & 9.73 & 9.55 & 15.98 & 8.83 & 10.76 \\
\hline Welfare use & $21.6 \%$ & $29.7 \%$ & $3.6 \%$ & $11.3 \%$ & $44.4 \%$ \\
\hline Monthly welfare income & $\$ 85$ & $\$ 124$ & $\$ 10$ & $\$ 37$ & $\$ 109$ \\
\hline Monthly welfare income $>0$ & $\$ 394$ & $\$ 418$ & $\$ 280$ & $\$ 323$ & $\$ 246$ \\
\hline Employed & $65.6 \%$ & $60.6 \%$ & $81.5 \%$ & $71.4 \%$ & $38.0 \%$ \\
\hline Out of the labor force & $27.8 \%$ & $32.3 \%$ & $14.4 \%$ & $22.5 \%$ & $48.9 \%$ \\
\hline Woman's Earnings & $\$ 1,088$ & $\$ 974$ & $\$ 1,743$ & $\$ 1,170$ & $\$ 389$ \\
\hline Woman's Earnings if $>0$ & $\$ 1,696$ & $\$ 1,641$ & $\$ 2,176$ & $\$ 1,678$ & $\$ 1,087$ \\
\hline Any food stamps income & $30.8 \%$ & $35.6 \%$ & $9.5 \%$ & $25.8 \%$ & $69.3 \%$ \\
\hline Food stamp income & $\$ 70$ & $\$ 83$ & $\$ 15$ & $\$ 55$ & $\$ 168$ \\
\hline Any SSI income & $5.1 \%$ & $4.8 \%$ & $3.7 \%$ & $5.3 \%$ & $19.1 \%$ \\
\hline SSI Income & $\$ 24$ & $\$ 22$ & $\$ 17$ & $\$ 25$ & $\$ 85$ \\
\hline
\end{tabular}


Poverty ratio 0-99\%

Poverty ratio 0-49\%

Whether other adults in the household

Household total income
$39.6 \%$

$20.0 \%$

$44.2 \%$

$\$ 2,306$
$42.3 \%$

$20.8 \%$

$44.3 \%$

$\$ 2,201$
$18.4 \%$

$8.7 \%$

$50.7 \%$

$\$ 2,954$
$38.3 \%$

$72.8 \%$

$45.4 \%$

$33.8 \%$

$\$ 1,252$

Table 5: First Stage regressions

\begin{tabular}{lccc}
\hline & $\mathrm{I}(0<\mathrm{S}<\mathrm{H})$ & $\mathrm{I}(\mathrm{S} \geq \mathrm{H})$ & $\mathrm{I}(\mathrm{S} \leq 0)$ \\
Variable & $(1)$ & $(2)$ & $(3)$ \\
\hline & & & \\
$\mathrm{I}(0<\mathrm{Z}<\mathrm{H})$ & $0.956^{* * *}$ & $0.047^{* * *}$ & $-249.054^{* * *}$ \\
$\mathrm{I}(\mathrm{Z} \geq \mathrm{H})$ & $(0.002)$ & $(0.002)$ & $(23.483)$ \\
& $0.271^{* * *}$ & $-0.732^{* * *}$ & $0.058^{* * *}$ \\
$\mathrm{I}(\mathrm{Z} \leq 0)$ & $(0.007)$ & $(0.007)$ & $(0.005)$ \\
& $-0.852^{* * *}$ & $0.059^{* * *}$ & $-0.081^{* * *}$ \\
Constant & $(0.006)$ & $(0.003)$ & $(0.006)$ \\
& 0.002 & 0.006 & $0.937^{* * *}$ \\
F Test (joint significance $)$ & $(0.011)$ & $(0.008)$ & $(0.044)$ \\
Prob $>$ F & & & 90.1 \\
& $115,336.9$ & $7,555.3$ & 0.000 \\
Observations & 0.000 & 0.000 & 544,234 \\
R-squared & & 544,234 & 0.18 \\
\hline
\end{tabular}

Notes: Predicted remaining benefits $\mathrm{Z}$ are defined using state time limits and exposure to time limits (calibrated by national average pre-reform welfare use by education and number of children). $\mathrm{H}$ denotes the eligibility horizon under time limits. Asterisks denote coefficients significantly different from zero at the $10 \%(*), 5 \%(* *)$, and $1 \%(* * *)$ level. Standard errors (in parentheses) account for heteroskedasticity and clustering across states. Estimates are weighted. 
Table 6

The effects of time limits on welfare use and dollar transfer amount

\begin{tabular}{|c|c|c|c|c|c|}
\hline Hypothesis & Variable & $\begin{array}{l}\text { Welfare Use } \\
\text { OLS } \\
(1)\end{array}$ & $\begin{array}{l}\text { Welfare Use } \\
\text { IV } \\
(2) \\
\end{array}$ & $\begin{array}{l}\text { TANF benefit (\$) } \\
\text { OLS } \\
(3)\end{array}$ & $\begin{array}{l}\text { TANF benefit (\$) } \\
\text { IV } \\
(4)\end{array}$ \\
\hline Enforcement & $\mathrm{I}(\mathrm{S} \leq 0)$ & $\begin{array}{l}0.297 * * * \\
(0.011)\end{array}$ & $\begin{array}{l}-0.801 * * * \\
(0.075)\end{array}$ & $\begin{array}{l}65.490 * * * \\
(3.561)\end{array}$ & $\begin{array}{c}-247.812 * * * \\
(23.840)\end{array}$ \\
\hline Banking & $\mathrm{I}(0<\mathrm{S}<\mathrm{H})$ & $\begin{array}{l}-0.002 \\
(0.003)\end{array}$ & $\begin{array}{l}-0.013 * * * \\
(0.004)\end{array}$ & $\begin{array}{c}0.335 \\
(1.254)\end{array}$ & $\begin{array}{l}-2.953 * * * \\
(1.319)\end{array}$ \\
\hline Unconstrained & $\mathrm{I}(\mathrm{S} \geq \mathrm{H})$ & $\begin{array}{l}-0.020 * * * \\
(0.004)\end{array}$ & $\begin{array}{c}0.014 \\
(0.008)\end{array}$ & $\begin{array}{c}0.284 \\
(1.549)\end{array}$ & $\begin{array}{l}10.481 * * * \\
(1.662)\end{array}$ \\
\hline Constant & & $\begin{array}{l}0.122 * * * \\
(0.037)\end{array}$ & $\begin{array}{l}-0.080 * \\
(0.043)\end{array}$ & $\begin{array}{c}2.974 \\
(17.602)\end{array}$ & $\begin{array}{c}-3.939 \\
(17.656)\end{array}$ \\
\hline Observations & & 544,234 & 544,234 & 544,234 & 544,234 \\
\hline
\end{tabular}

Notes: In the IV estimation, the three functions of remaining benefits $\mathrm{S}$ are instrumented by the same three functions of predicted remaining benefits $\mathrm{Z}$, defined using state time limits and exposure to time limits (calibrated by national average pre-reform welfare use by education and number of children). $\mathrm{H}$ denotes the eligibility horizon under time limits. Asterisks denote coefficients significantly different from zero at the $10 \%(*), 5 \%(* *)$, and $1 \%(* * *)$ level. Standard errors (in parentheses) account for heteroskedasticity and clustering across states. Estimates are weighted.

Table 7. The effects of time limits on welfare use by type of time limit policy

\begin{tabular}{|c|c|c|c|c|c|}
\hline Hypothesis & Variable & $\begin{array}{l}\text { Termination TL } \\
\text { IV } \\
(1)\end{array}$ & $\begin{array}{l}\text { Reduction TL } \\
\text { IV } \\
(2) \\
\end{array}$ & $\begin{array}{l}\text { 60-month } \\
\text { lifetime limit } \\
\text { IV } \\
(3)\end{array}$ & $\begin{array}{l}\text { Shorter lifetime limit } \\
\text { or intermittent } \\
\text { IV } \\
\text { (4) }\end{array}$ \\
\hline Enforcement & $\mathrm{I}(\mathrm{S} \leq 0)$ & $\begin{array}{l}-1.148 * * * \\
(0.099)\end{array}$ & $\begin{array}{l}0.496 * * * \\
(0.072)\end{array}$ & $\begin{array}{c}0.000 \\
(0.000)\end{array}$ & $\begin{array}{l}-0.817 * * * \\
(0.086)\end{array}$ \\
\hline Banking & $\mathrm{I}(0<\mathrm{S}<\mathrm{H})$ & $\begin{array}{l}-0.021 * * * \\
(0.004)\end{array}$ & $\begin{array}{l}-0.009 \\
(0.009)\end{array}$ & $\begin{array}{l}-0.018 * * * \\
(0.005)\end{array}$ & $\begin{array}{l}-0.018 * * * \\
(0.005)\end{array}$ \\
\hline Unconstrained & $\mathrm{I}(\mathrm{S} \geq \mathrm{H})$ & $\begin{array}{l}0.030 * * * \\
(0.006)\end{array}$ & $\begin{array}{c}0.019 \\
(0.011)\end{array}$ & $\begin{array}{l}0.075 * * * \\
(0.009)\end{array}$ & $\begin{array}{l}-0.028 * * * \\
(0.007)\end{array}$ \\
\hline Constant & & $\begin{array}{l}0.252^{* * * *} \\
(0.050)\end{array}$ & $\begin{array}{l}0.263 * * * \\
(0.074)\end{array}$ & $\begin{array}{l}-0.094 * \\
(0.052)\end{array}$ & $\begin{array}{l}0.322 * * * \\
(0.072)\end{array}$ \\
\hline Observations & & 394,576 & 170,942 & 309,226 & 256,292 \\
\hline
\end{tabular}

The models in Columns 1 and 2 only include observations for states with termination or reduction time limits respectively. States adopting reduction time limits are: AZ, CA, IN, MD, NY, OR and RI. Model in Column 3 only includes observations for states imposing a 60-month lifetime limit, while model in Column 4 includes observations for states imposing lifetime limits shorter than 60-month (AK, CT, FL, GA, ID, IN, NE, UT) or intermittent limits (AZ, DE, FL, LA, MA, NE, NV, NC, OH, OR, SC, TN, TX, VA). 
Table 8

The effects of time limits on employment and earnings

\begin{tabular}{|c|c|c|c|c|c|}
\hline Hypothesis & Variable & $\begin{array}{l}\text { Employed } \\
\text { IV } \\
(1) \\
\end{array}$ & $\begin{array}{l}\text { Out of Labor Force } \\
\text { IV } \\
(2)\end{array}$ & $\begin{array}{l}\text { Earnings } \\
\text { IV } \\
(3) \\
\end{array}$ & $\begin{array}{l}\text { Log Earnings } \\
\text { IV } \\
(4) \\
\end{array}$ \\
\hline Enforcement & $\mathrm{I}(\mathrm{S} \leq 0)$ & $\begin{array}{l}0.210 * * * \\
(0.073)\end{array}$ & $\begin{array}{l}-0.295 * * * \\
(0.076)\end{array}$ & $\begin{array}{l}-125.700 \\
(193.674)\end{array}$ & $\begin{array}{c}0.319 \\
(0.229)\end{array}$ \\
\hline Banking & $\mathrm{I}(0<\mathrm{S}<\mathrm{H})$ & $\begin{array}{l}0.024 * * * \\
(0.004)\end{array}$ & $\begin{array}{l}-0.028 * * * \\
(0.004)\end{array}$ & $\begin{array}{l}69.300 * * * \\
(13.224)\end{array}$ & $\begin{array}{l}0.018 * \\
(0.010)\end{array}$ \\
\hline Unconstrained & $\mathrm{I}(\mathrm{S} \geq \mathrm{H})$ & $\begin{array}{l}-0.042 * * * \\
(0.006)\end{array}$ & $\begin{array}{l}0.021 * * * \\
(0.006)\end{array}$ & $\begin{array}{c}19.707 \\
(25.772)\end{array}$ & $\begin{array}{l}0.044 * * * \\
(0.015)\end{array}$ \\
\hline Constant & & $\begin{array}{l}-0.090 * * \\
(0.043)\end{array}$ & $\begin{array}{l}0.944 * * * \\
(0.045)\end{array}$ & $\begin{array}{r}-1,219.8 \\
(80.068)\end{array}$ & $\begin{array}{l}4.825^{* * *} \\
(0.111)\end{array}$ \\
\hline Observations & & 544,234 & 544,234 & 544,234 & 354,213 \\
\hline
\end{tabular}

Notes: In the IV estimation, the three functions of remaining benefits $\mathrm{S}$ are instrumented by the same three functions of predicted remaining benefits $\mathrm{Z}$, defined using state time limits and exposure to time limits (calibrated by national average pre-reform welfare use by education and number of children). $\mathrm{H}$ denotes the eligibility horizon under time limits. Asterisks denote coefficients significantly different from zero at the $10 \%(*), 5 \%(* *)$, and $1 \%(* * *)$ level. Standard errors (in parentheses) account for heteroskedasticity and clustering across states. Estimates are weighted.

Table 9

The effects of time limits on Food Stamps and SSI use

\begin{tabular}{|c|c|c|c|c|c|}
\hline Hypothesis & Variable & $\begin{array}{l}\text { Food Stamps Use } \\
\text { IV } \\
(1) \\
\end{array}$ & $\begin{array}{l}\text { Food Stamps Income }(\$) \\
\text { IV } \\
(2) \\
\end{array}$ & $\begin{array}{l}\text { SSI Use } \\
\text { IV } \\
(3)\end{array}$ & $\begin{array}{l}\text { SSI income }(\$) \\
\text { IV } \\
(4)\end{array}$ \\
\hline Enforcement & $\mathrm{I}(\mathrm{S} \leq 0)$ & $\begin{array}{l}-0.215^{* * *} \\
(0.077)\end{array}$ & $\begin{array}{l}-47.546^{* * * *} \\
(22.519)\end{array}$ & $\begin{array}{l}-0.061 \\
(0.046)\end{array}$ & $\begin{array}{l}-76.427 * * * \\
(24.961)\end{array}$ \\
\hline Banking & $\mathrm{I}(0<\mathrm{S}<\mathrm{H})$ & $\begin{array}{l}-0.021 * * * \\
(0.004)\end{array}$ & $\begin{array}{l}-2.435^{* *} \\
(0.971)\end{array}$ & $\begin{array}{c}-0.007 * * * \\
(0.002)\end{array}$ & $\begin{array}{l}-3.722 * * * \\
(1.096)\end{array}$ \\
\hline Unconstrained & $\mathrm{I}(\mathrm{S} \geq \mathrm{H})$ & $\begin{array}{l}0.015 * * * \\
(0.006)\end{array}$ & $\begin{array}{l}2.981 * * \\
(1.303)\end{array}$ & $\begin{array}{c}-0.016 * * * \\
(0.003)\end{array}$ & $\begin{array}{l}-7.698 * * * \\
(1.780)\end{array}$ \\
\hline Constant & & $\begin{array}{l}-0.064 \\
(0.040)\end{array}$ & $\begin{array}{c}-127.626^{* *} \\
(10.665)\end{array}$ & $\begin{array}{c}-0.178 * * * \\
(0.026)\end{array}$ & $\begin{array}{l}-78.786 * * * \\
(13.561)\end{array}$ \\
\hline Observations & & 544,234 & 544,234 & 544,234 & 544,234 \\
\hline
\end{tabular}

Notes: In the IV estimation, the three functions of remaining benefits $\mathrm{S}$ are instrumented by the same three functions of predicted remaining benefits $\mathrm{Z}$, defined using state time limits and exposure to time limits (calibrated by national average pre-reform welfare use by education and number of children). $\mathrm{H}$ denotes the eligibility horizon under time limits. Asterisks denote coefficients significantly different from zero at the $10 \%(*), 5 \%(* *)$, and $1 \%(* * *)$ level. Standard errors (in parentheses) account for heteroskedasticity and clustering across states. Estimates are weighted. 
Table 10: The effects of time limits on family poverty rates, household income and living arrangements

\begin{tabular}{|c|c|c|c|c|c|}
\hline Hypothesis & Variable & $\begin{array}{l}\text { Poverty ratio } \\
0-99 \% \\
\text { IV } \\
\text { (1) }\end{array}$ & $\begin{array}{l}\text { Poverty ratio } \\
0-49 \% \\
\text { IV } \\
\text { (2) }\end{array}$ & $\begin{array}{l}\text { Household } \\
\text { Income (\$) } \\
\text { IV } \\
(3)\end{array}$ & $\begin{array}{l}\text { Other adults living } \\
\text { in the household } \\
\text { IV } \\
\text { (4) }\end{array}$ \\
\hline Enforcement & $\mathrm{I}(\mathrm{S} \leq 0)$ & $\begin{array}{c}0.075 \\
(0.077)\end{array}$ & $\begin{array}{r}0.134 * \\
(0.080)\end{array}$ & $\begin{array}{c}-29.909 \\
(280.650)\end{array}$ & $\begin{array}{l}0.387 * * * \\
(0.074)\end{array}$ \\
\hline Banking & $\mathrm{I}(0<\mathrm{S}<\mathrm{H})$ & $\begin{array}{l}-0.009^{* *} \\
(0.005)\end{array}$ & $\begin{array}{l}-0.020^{* *} \\
(0.004)\end{array}$ & $\begin{array}{c}17.819 \\
(24.713)\end{array}$ & $\begin{array}{l}-0.026^{* * * *} \\
(0.004)\end{array}$ \\
\hline Unconstrained & $\mathrm{I}(\mathrm{S} \geq \mathrm{H})$ & $\begin{array}{l}-0.022 * * * \\
(0.007)\end{array}$ & $\begin{array}{l}0.018 * * * \\
(0.006)\end{array}$ & $\begin{array}{c}61.992 \\
(41.197)\end{array}$ & $\begin{array}{l}0.056^{* * * *} \\
(0.007)\end{array}$ \\
\hline Constant & & $\begin{array}{l}-0.309 * * * \\
(0.044)\end{array}$ & $\begin{array}{l}0.247^{* * *} \\
(0.043)\end{array}$ & $\begin{array}{l}3,867.009 * * * \\
(161.191)\end{array}$ & $\begin{array}{l}1.440^{* * *} \\
(0.045)\end{array}$ \\
\hline Observations & & 544,234 & 544,234 & 544,234 & 544,234 \\
\hline
\end{tabular}

Notes: In the IV estimation, the three functions of remaining benefits $\mathrm{S}$ are instrumented by the same three functions of predicted remaining benefits $\mathrm{Z}$, defined using state time limits and exposure to time limits (calibrated by national average pre-reform welfare use by education and number of children). $\mathrm{H}$ denotes the eligibility horizon under time limits. Asterisks denote coefficients significantly different from zero at the $10 \%(*), 5 \%(* *)$, and $1 \%(* * *)$ level. Standard errors (in parentheses) account for heteroskedasticity and clustering across states. Estimates are weighted. 
Figure 1

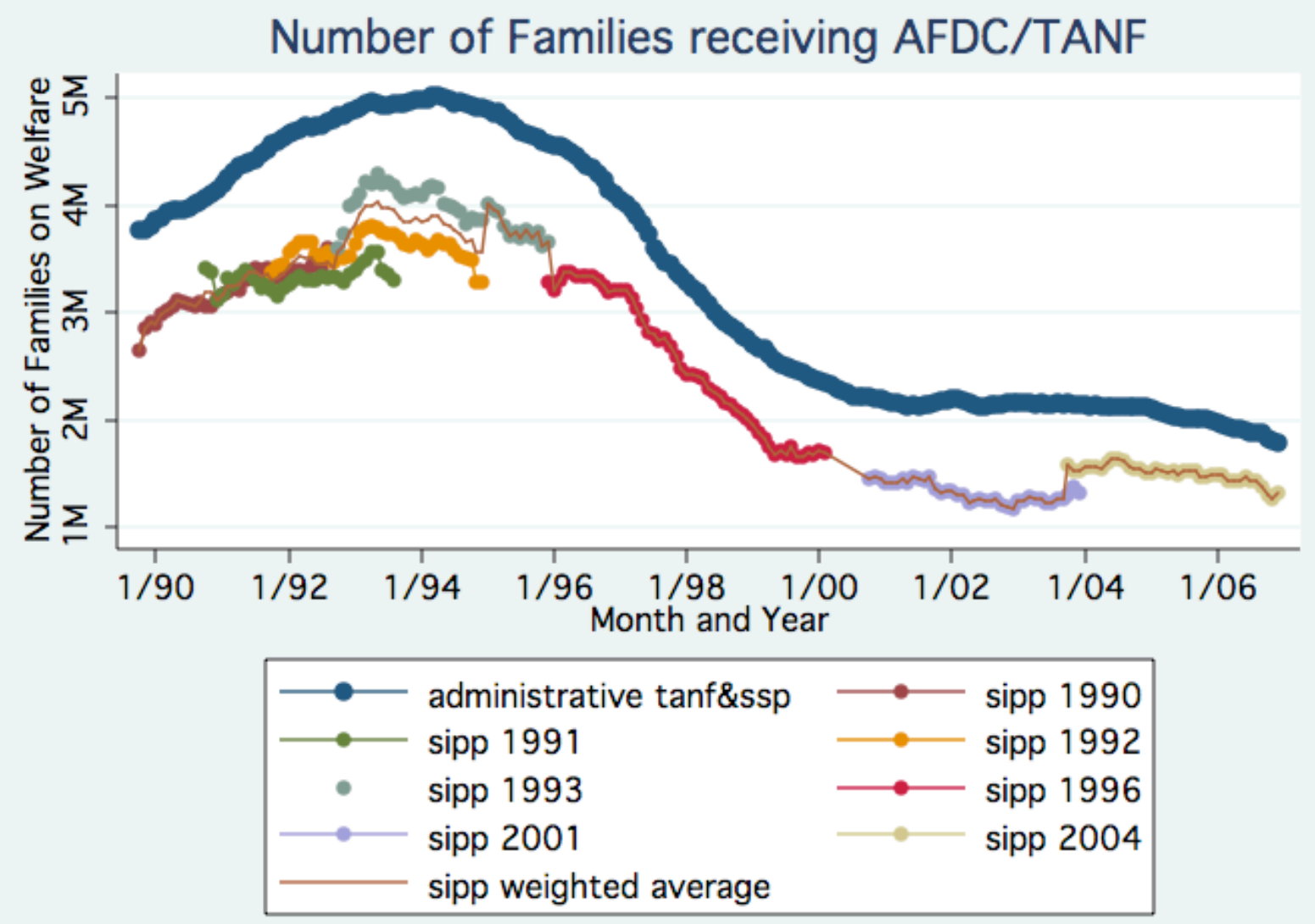

Source: Data on monthly state-level counts of AFDC/TANF cases are from ACF and includes both cases funded with federal TANF block grants or state separate programs (ssp) (http://www.acf.hhs.gov/programs/ofa/data-reports/caseload/caseload_archive.html). For AFDC, only "basic cases" are counted. For TANF, one-parent and no-parent cases are summed.

SIPP weighted averages for the period covered by multiple panels are obtained using adjustment factors that reflect the relative sample size of each panel. 
Figure 2

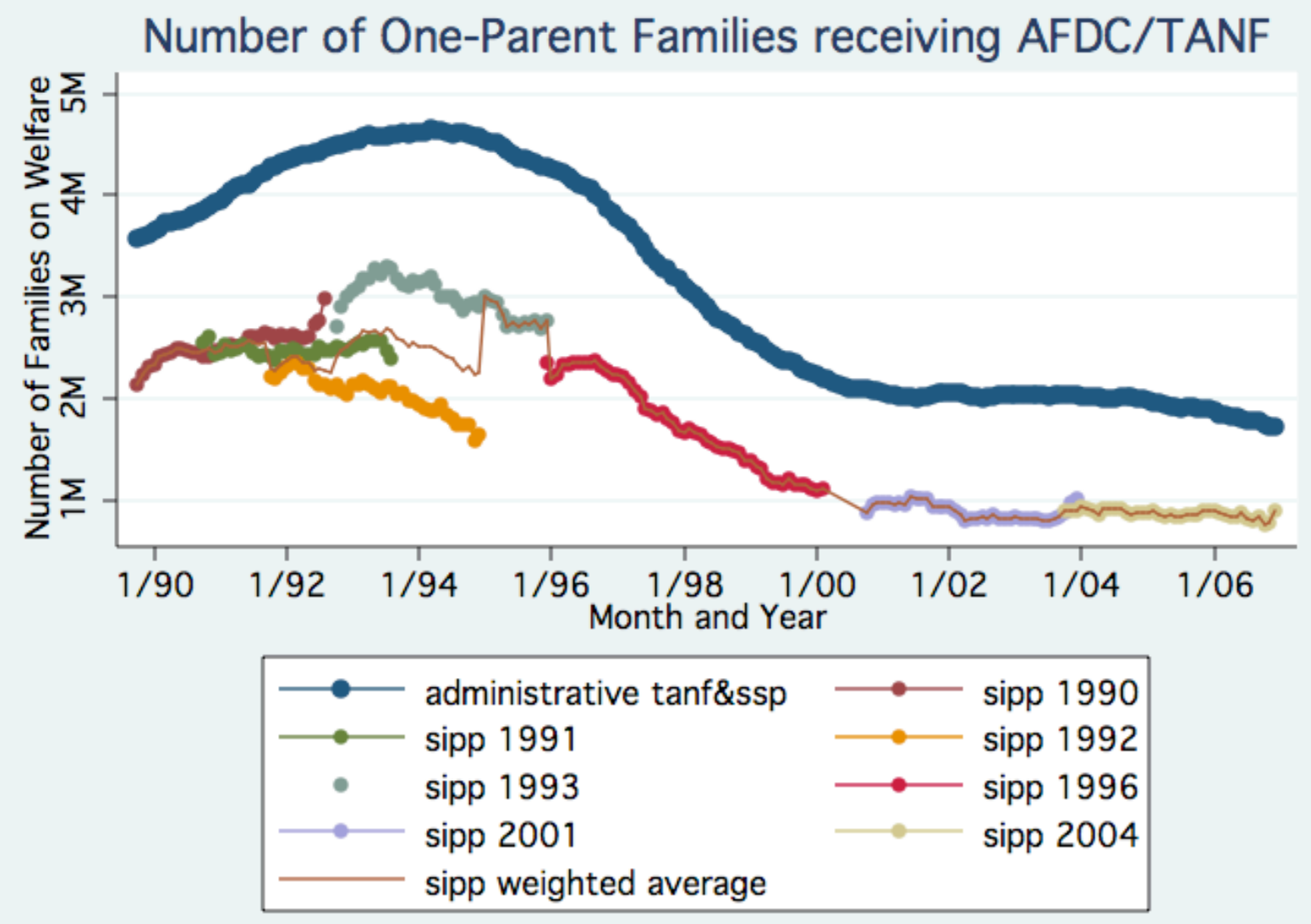

Source: Data on monthly state-level counts of AFDC/TANF cases are from ACF and includes both cases funded with federal TANF block grants or state separate programs (ssp) (http://www.acf.hhs.gov/programs/ofa/data-reports/caseload/caseload_archive.html). For AFDC, only "basic cases" are counted. For TANF, one-parent and no-parent cases are summed.

SIPP weighted averages for the period covered by multiple panels are obtained using adjustment factors that reflect the relative sample size of each panel. 